\title{
9. A 160,000-YEAR HIGH-RESOLUTION RECORD OF QUANTITY AND COMPOSITION OF ORGANIC CARBON IN THE SANTA BARBARA BASIN (SITE 893) ${ }^{1}$
}

\author{
Ruediger Stein ${ }^{2}$ and Frank R. Rack ${ }^{3}$
}

\begin{abstract}
To identify the factors controlling the organic-carbon accumulation in the Santa Barbara Basin and their relationship to the (global) climatic history through the last 160,000 years, total organic carbon (TOC), Rock-Eval parameters, and C/N ratios were determined on 990 samples from Hole 893A. For a selected set of samples, $n$-alkanes and pristane/phytane ratios were also determined. In the major lithologies, TOC values vary between $1 \%$ and $4 \%$, with the higher values more typical for the interglacials and the lower values more typical for the glacials. The source of the organic matter is a mixed marine/terrigenous type, with a higher marine proportion during interglacials. Gray flood/turbidity deposits and sandy turbidites are characterized by significantly lower TOC values of $0.9 \%-1.8 \%$ and $0.1 \%-0.3 \%$, respectively, with a clear terrigenous origin.

During the Holocene, increased surface-water productivity and the inflow of oxygen-depleted waters from the East Pacific probably resulted in anoxic bottom water and, thus, in the preservation of varved-like laminations and large amounts of marine organic carbon. During the warm interstadials $5 \mathrm{e}$ and $5 \mathrm{a}$, surface-water productivity and, thus, marine organic carbon flux also increased; anoxic bottom water conditions, however, were not reached throughout, as indicated by the dominance of massive non-laminated sediments. Furthermore, distinct higher-frequency variations of a few thousands of years are present in Stages 1 , $5 \mathrm{a}$, and $5 \mathrm{c}$. During glacial Stages 6 and 4 to 2 and cold interstadials $5 \mathrm{~d}$ and $5 \mathrm{~b}$, surface-water productivity was reduced and the bottom-water conditions in the Santa Barbara Basin were more oxygenated. At those times of lowered sea level, also the supply of terrigenous organic matter was probably increased.
\end{abstract}

\section{INTRODUCTION}

In the past, paleoceanographic and paleoclimatic studies of Quaternary sediments from the Santa Barbara Basin, California, were restricted to the Holocene time interval. Numerous high-resolution studies of varve chronology and sedimentology, oxygen stable isotopes, microfossil assemblages (foraminifers, radiolarians, diatoms, pollen), and biomarker demonstrated that distinct changes in precipitation, terrigenous sediment input, surface-water temperature, intensity of the California Current, surface-water productivity, and/or oxygenation of water masses occurred during the Holocene (e.g., Soutar and Crill, 1977; Heusser, 1978; Pisias, 1978; Dunbar, 1983; Lange et al., 1990; Reimers et al., 1990; Schimmelmann et al., 1990; Bernhard and Reimers, 1991; Kennedy and Brassell, 1992a, b). The extremely high resolution of some of these investigations even allows the identification of historic El Niño events (e.g., Dunbar, 1983; Lange et al., 1987; Kennedy and Brassell, 1992a). From these results, it is obvious that the Santa Barbara Basin is of major importance for research of the (global) climate system and its change through time.

The drilling of the almost 200-m-thick sedimentary sequence of Ocean Drilling Program Site 893 offers the opportunity to extend high-resolution studies of climatic change in the Santa Barbara Basin to pre-Holocene times (i.e., back to about 160,000 years ago; Kennett, Baldauf, et al., 1994). The major purposes of this study are (1) to quantify and characterize the organic carbon in the Site 893 sediments, (2) to identify factors controlling the organic-carbon accumulation, and (3) to correlate the organic-carbon data with the climatic history.

'Kennett, J.P., Baldauf, J.G., and Lyle, M. (Eds.), 1995. Proc. ODP, Sci. Results, 146 (Pt. 2): College Station, TX (Ocean Drilling Program).

2Alfred-Wegener-Institute for Polar and Marine Research, Columbusstrasse, 27568 Bremerhaven, Federal Republic of Germany.

3ocean Mapping Group, University of New Brunswick, Fredericton, N.B.. Canada E3B 5A3.

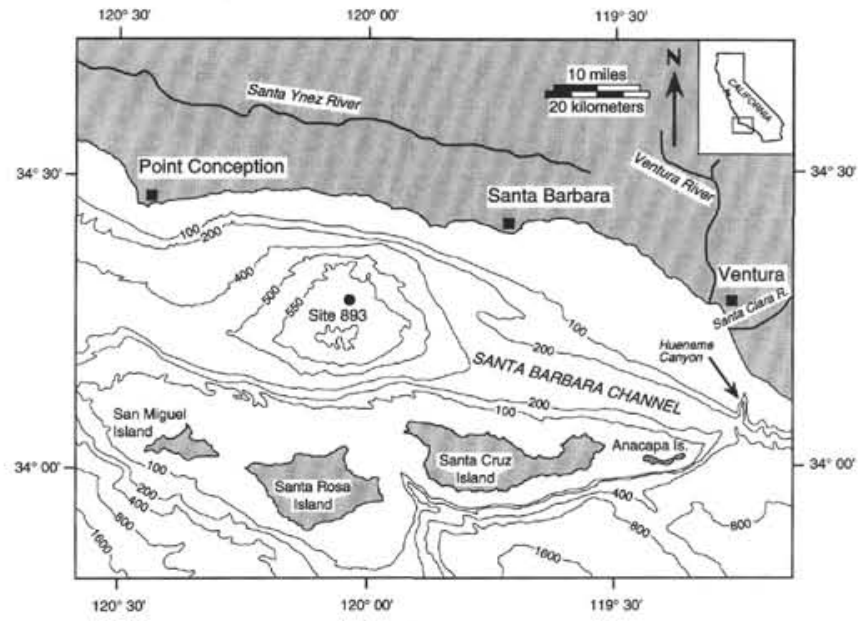

Figure 1. Map of the Santa Barbara Basin and location of Site 893 (from Kennett, Baldauf, et al., 1994). Bathymetry in meters.

\section{MODERN SETTING IN THE SANTA BARBARA BASIN}

The Santa Barbara Basin is a semi-closed basin on the southern California continental margin (Fig. 1). Maximum water depth is about $600 \mathrm{~m}$. The sill depth to the west is only $475 \mathrm{~m}$. Because this depth lies within the East Pacific Oxygen Minimum Zone, the bottom water in the Santa Barbara Basin deeper than the sill depth is suboxic (Sholkovitz and Gieskes, 1971; Kennett, Baldauf, et al., 1994). Together with the abundant flux of organic material from the highly productive surface waters, this leads to the accumulation of anoxic muds at the seafloor. These sediments are characterized by distinctly enriched organic-carbon contents and the preservation of annual light/ 
dark laminations (varves) caused by seasonal variations in the biogenic and terrigenous sediment, growth of bacterial mats, and/or bottom-water oxygenation (e.g., Soutar and Crill, 1977; Lange et al., 1987, 1990; Reimers et al., 1990; Baumgartner et al., 1991; Schimmelmann et al., 1992). The high surface-water productivity is mainly controlled by the California Current System (CCS), which itself is triggered by ocean-atmosphere interactions over broad areas of the Pacific Ocean. Seasonal variations in the CCS caused by changes in wind strength and direction result in changes of surface-water temperatures, upwelling intensity, and surface-water productivity (Hickey, 1992; Kennett, Baldauf, et al., 1994).

\section{MAJOR LITHOLOGIES AT SITE 893}

Site 893 (which consists of Hole 893A and Hole 893B) was drilled at $34^{\circ} 17.25^{\prime} \mathrm{N}, 120^{\circ} 02.2^{\prime} \mathrm{W}$ in the central part of the Santa Barbara Basin, $20 \mathrm{~km}$ south of the Santa Barbara coastline at a water depth of $576.5 \mathrm{~m}$ (Fig. 1). At this site, a 196.5-m-thick sequence of upper Quaternary terrigenous silt and clay with variable contents of calcareous nannofossils and diatoms was recovered (Fig. 2). Based on oxygen-isotope stratigraphy, the sequence represents isotope Stages 1 to 6 (i.e., about the last 160,000 years; Ingram and Kennett, this volume). The sediments at Site 893 are considered to form one lithologic unit that can be divided into six subunits (Fig. 2; Kennett, Baldauf, et al., 1994):

Subunit IA (Hole 893A, 0 to 24.25 mbsf) mainly consists of olive gray diatom nannofossil clayey silt and diatom nannofossil silty clay. The subunit is characterized by variably preserved laminations throughout most of the interval. Thin $(1-15 \mathrm{~cm})$ gray beds of clayey silt to silty clay are commonly interbedded (Pl. 1, Fig. 1).

Subunit IB (Hole 893A, 24.25 to $37.0 \mathrm{mbsf}$ ) is composed of olive gray silty clay; microfossils only occur in minor amounts $(2 \%-10 \%)$. Laminations are completely absent.

Subunit IC (Hole 893A, 37.0 to $131.0 \mathrm{mbsf}$ ) consists of olive gray silty clay and clayey silt with diatom silty clay ( $\mathrm{Pl}$. 1, Figs. 2-5). The subunit is characterized by the intermittent presence of laminations. Four medium to thick beds of sand occur between 56.5 and 64.7 mbsf, and a 2.5-m-thick sand bed occurs at 114.4-116.9 mbsf.

Subunit ID (Hole 893A, 131.0 to $145.5 \mathrm{mbsf}$ ) consists of olive gray diatom silty clay (Pl. 1, Fig. 6). Except for two short intervals in the middle part, lamination occurs throughout. The subunit contains abundant thin $(1-15 \mathrm{~cm})$ gray beds of clayey silt to silty clay. Thin, millimeter to submillimeter laminae of pale olive diatom ooze are present sporadically.

Subunit IE (Hole 893A, 145.5 to 160.5 mbsf) consists of olive gray to pale olive silty clay and clayey silt with diatom silty clay. Laminations are completely absent.

Subunit IF (Hole 893A, 160.5 to 196.5 mbsf) consists of olive gray silty clay, clayey silt, and diatom silty clay. The sequence is characterized by an alternation of 0.2 - to 3.0 -m-thick packets of laminated diatom silty clay and homogeneous sediment.

\section{METHODS}

For the high-resolution study on organic-carbon variations, the 196.5-m-thick sediment sequence of Hole 893A was routinely sampled at $20-\mathrm{cm}$ intervals, resulting in a total of 990 samples (Table 1 on CD-ROM, back pocket of this volume). Taking sedimentation rates of 75 to $333 \mathrm{~cm} / \mathrm{k} . \mathrm{y}$. (Table 2; Ingram and Kennett, this volume), the time resolution is about 60 to 250 years. Another high-resolution study on carbonate and organic-carbon variations was performed by Gardner and Dartnell (this volume). The combination of both data sets gives a time resolution of 30 to 125 years.
Total carbon, nitrogen, and organic carbon were determined on ground bulk samples and carbonate-free sediment samples by means of a Heraeus $\mathrm{CHN}$-analyzer. Carbon measurements have an accuracy of $0.02 \%$. The carbonate content was calculated as:

$$
\mathrm{CaCO}_{3}=(\mathrm{TC}-\mathrm{TOC}) \cdot 8.333
$$

where $\mathrm{TC}=$ total carbon and $\mathrm{TOC}=$ total organic carbon (both in $\mathrm{wt} \%$ of the bulk sample). It is assumed that all carbonate is calcite, which has been proved by X-ray diffraction (XRD) analysis for a selected set of samples (see Stein, this volume). $\mathrm{C} / \mathrm{N}$ ratios, as indicator for the composition of the organic carbon, were calculated as "total organic carbon/total nitrogen ratios."

Rock-Eval pyrolysis was conducted on bulk sediment samples to determine the amount of hydrocarbons already present in the sample ( $\mathrm{S} 1$ peak in mg hydrocarbons per gram sediment), the amount of hydrocarbons generated by pyrolytic degradation of the kerogen during heating of up to $550^{\circ} \mathrm{C}$ (S2 peak in mg hydrocarbon per gram sediment), the amount of carbon dioxide generated during heating of up to $390^{\circ} \mathrm{C}$ ( $\mathrm{S} 3$ peak in $\mathrm{mg}$ carbon dioxide per gram sediment), and the temperature of maximum pyrolysis yield (Tmax value in ${ }^{\circ} \mathrm{C}$ ) (Espitalié et al.; 1977; Peters, 1986). As further indicators for the composition of the organic matter, the Rock-Eval parameters hydrogen (HI) and oxygen index values (OI) were used (cf., Tissot and Welte, 1984; Stein, 1991, and further references therein). The HI value corresponds to the quantity of pyrolyzable hydrocarbons per gram TOC ( $\mathrm{mgHC} / \mathrm{gC})$; the OI value corresponds to the quantity of carbon dioxide per gram $\mathrm{TOC}\left(\mathrm{mgCO}_{2} / \mathrm{gC}\right)$,

For liquid extraction, samples were treated successively with methanol, methanol/dichloromethane (1:1), and dichloromethane (cf., Farrimond et al., 1990). After each step, the sample was centrifuged and its clear extract decanted; all extracts were combined. As internal standard, squalane was added. Then, the total extract was fractionated by column chromatography. The "hydrocarbon fraction" was collected upon elution with hexane and injected into a HP5890 (Series II) gas chromatograph. The GC was equipped with a silica capillary column $(50-\mathrm{m} \times 0.32 \mathrm{~mm} ; 0.17 \mu \mathrm{m}$ film of dimethyl-polysiloxan). The temperature program was as follows: $60^{\circ} \mathrm{C}$ for $1 \mathrm{~min}$; $60^{\circ} \mathrm{C}$ to $150^{\circ} \mathrm{C}$ at $10^{\circ} \mathrm{C} / \mathrm{min} ; 150^{\circ} \mathrm{C}$ to $300^{\circ} \mathrm{C}$ at $4^{\circ} \mathrm{C} / \mathrm{min}$; isothermal at $300^{\circ} \mathrm{C}$ for $45 \mathrm{~min}$. Helium was used as carrier gas. The $n$-alkanes $\left(\mathrm{C}_{15}-\mathrm{C}_{32}\right)$, and phytane and pristane were identified on the basis of retention times.

Mass accumulation rates of total organic carbon (MARTOC) were calculated according to van Andel et al. (1975):

$$
\begin{gathered}
\text { MARTOC }=(\mathrm{TOC} / 100) \cdot \mathrm{LSR} \cdot[\mathrm{WBD}-1.026 \cdot(\mathrm{PO} / 100)] \\
=(\mathrm{TOC} / 100) \cdot \mathrm{LSR} \cdot \mathrm{DD}
\end{gathered}
$$

where $\mathrm{TOC}=$ total organic carbon $(\mathrm{wt} \%), \mathrm{LSR}=$ linear sedimentation rate $(\mathrm{cm} / \mathrm{k} . \mathrm{y}),. \mathrm{WBD}=$ wet bulk density $\left(\mathrm{g} / \mathrm{cm}^{3}\right), \mathrm{DD}=$ dry density $\left(\mathrm{g} / \mathrm{cm}^{3}\right)$, and $\mathrm{PO}=$ porosity $(\%)$. The linear sedimentation rates are based on $\mathrm{AMS}^{14} \mathrm{C}$ chronology and oxygen-isotope stratigraphy (Ingram and Kennett, this volume; Kennett, this volume); for determination of physical properties, see Kennett, Baldauf, et al. (1994).

\section{RESULTS}

The data determined on 990 samples are summarized in Table 1. In this paper, the organic-carbon data including total organic carbon (TOC), Rock-Eval parameters, $\mathrm{C} / \mathrm{N}$ ratios, and $n$-alkanes are presented and discussed. The carbonate data also included in Table 1 are discussed in Gardner and Dartnell (this volume). 

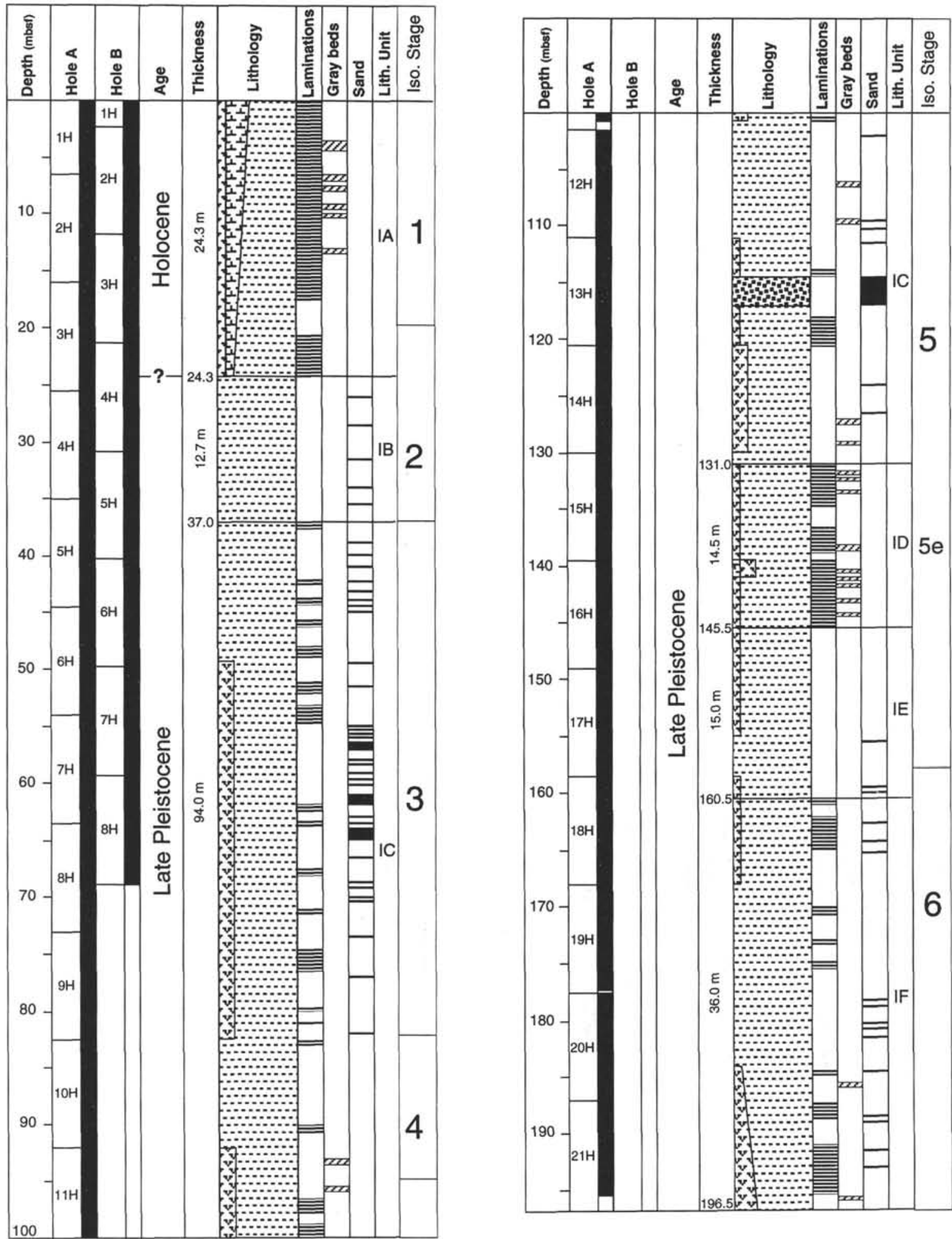

\section{EI nannofossils Fic foraminifers 层 laminations}

Figure 2. Lithostratigraphy of Holes 893A and 893B (from Kennett, Baldauf, et al., 1994). Numbers 1 to 6 at the right indicate oxygen-stable-isotope stages; the laminated Subunit ID approximately corresponds to upper warm interstadial $5 \mathrm{e}$ (Kennett, this volume). 
In the following description of the organic-carbon data vs. depth, the void-corrected depth values were used (Table 1; Rack and Merrill, this volume). In general, TOC values vary between $1 \%$ and $3 \%$ (Fig. 3; Table 1). The intervals from 196.1 to $150 \mathrm{mbsf}$ (corresponding approximately to lithologic Subunits IE and IF) and 95.2 to 20 mbsf (corresponding to the upper half of Subunit IC and Subunit IB) are characterized by low-amplitude variations of TOC between $1.2 \%$ and $2.2 \%$. The few exceptions with very low TOC contents of $0.1 \%$ to $0.3 \%$, especially between about 56 and $65 \mathrm{mbsf}$, correspond to sandy turbiditic layers (Figs. 2 and 3). Between 150 and 95.2 mbsf as well as in the upper $20 \mathrm{~m}$, fluctuations in TOC content are significantly higher, ranging between $1 \%$ and $4 \%$. In Sample 146-893A-12H-4, 89-90 cm (106.57 mbsf), and near-surface Sample 146-893A-1H-1, $31-32 \mathrm{~cm}(0.31 \mathrm{mbsf})$, the absolute TOC maximum values of $4.58 \%$ and $4.38 \%$, respectively, were measured. Minimum TOC values of $0.08 \%-0.12 \%$ characterize the $2.5-\mathrm{m}$-thick sand bed at 114.4-116.9 mbsf (Figs. 2 and 3). The short-term high-amplitude variations are most prominent in the laminated intervals of Subunits ID and IA. The distinct TOC minima between $1 \%$ and $1.7 \%$ recorded in these two subunits are from the macroscopically visible gray clayey silt to silty clay beds (Figs. 2 and 3 ).

To get an estimate of the composition of the organic-carbon fraction (i.e., to estimate the amount of terrigenous and marine proportions), Rock-Eval pyrolysis parameters (S2 peak, HI and OI values) and elemental analysis data ( $\mathrm{C} / \mathrm{N}$ ratios) are useful indicators in organic-carbon-rich (TOC $>0.5 \%$ ), immature sediments (Figs. 3 and 4 ; Tissot and Welte, 1984; Stein, I991). In immature sediments, HI values of $<100 \mathrm{mgHC} / \mathrm{gC}$ are typical of terrigenous organic matter (kerogen type III), whereas $\mathrm{HI}$ values of 300 to $800 \mathrm{mgHC} / \mathrm{gC}$ are typical of marine organic matter (kerogen types I and II) (Tissot and Welte, 1984). Tmax values of $<425^{\circ} \mathrm{C}$ (Fig. 3 ) display the thermal immaturity of the organic carbon; thus, the HI values determined in the organic-carbon-rich sediments of Site 893 should yield reliable data. C/ $\mathrm{N}$ ratios can be used as further indicator for the origin of the organic matter: $\mathrm{C} / \mathrm{N}$ ratios of marine organic matter (mainly phytoplankton and zooplankton) are around 6 , whereas terrigenous organic matter (mainly from higher plants) has $\mathrm{C} / \mathrm{N}$ ratios of $>15$ (e.g., Bordovskiy, 1965; Scheffer and Schachtschabel, 1984). For more precise determinations of the marine and terrigenous proportions of the organic-carbon fraction, other methods such as kerogen/coal petrography and gas chromatography (GC) are required. The distribution of $n$-alkanes determined using GC techniques allows an identification of contributions of land-derived vascular plant material (characterized by longchain $\mathrm{C}_{29}$ and $\mathrm{C}_{31} n$-alkanes) and of marine phytoplankton (dominated by $C_{17} n$-alkane) (e.g., Blumer et al., 1971; Kollatukudy, 1976; Prahl and Muehlhausen, 1989). These much more sophisticated methods, however, can only be applied for a small set of selected samples because they are very time consuming (see also Hinrichs et al., this volume), whereas Rock-Eval pyrolysis and elemental analysis (as well as $\delta^{13} \mathrm{C}_{\mathrm{org}}$, however, not used in this study) have the advantage of being fast and requiring small samples so many analyses can be performed.

Based on Rock-Eval data (Figs. 3 and 4), the organic carbon of the Site 893 sediments has in general a mixed terrigenous/marine source. Hydrogen index values of 100 to $250 \mathrm{mgHC} / \mathrm{gC}$ suggest that significant proportions of marine organic matter have been preserved (Figs. 3 and 4). A large number of samples, on the other hand, have HI values between 50 and $100 \mathrm{mgHC} / \mathrm{gC}$, indicating the dominantly terrigenous origin of the organic matter. Particularly, the laminated intervals (corresponding to lithologic Subunits ID and IA) are characterized by high-amplitude variations in $\mathrm{S} 2$ and $\mathrm{HI}$ values, suggesting short-term variations in organic-carbon composition (Fig. 3). The minimum S2 and $\mathrm{HI}$ peaks are mostly from gray beds. The increased TOC contents at depths of 156.8 to $95.2 \mathrm{mbsf}$ and in the upper $20 \mathrm{~m}$ coincide with increased $\mathrm{HI}$ values and very high $\mathrm{S} 2$ peaks indicating increased amounts of marine organic carbon preserved in the sediments (Fig. 3).

The C/N ratios generally vary between 6 and 12 and support the Rock-Eval results, indicating a mixed type of organic matter (Fig. 3). However, some disagreements between both data sets occur in the details. According to the $\mathrm{C} / \mathrm{N}$ signal, some increased amounts of (terrigenous) higher plant material should be present at depths of 150 to $138 \mathrm{mbsf}, 130$ to $122 \mathrm{mbsf}, 50$ to $38 \mathrm{mbsf}$, and 20 to $8 \mathrm{mbsf}$ (Fig. 3). The very low $\mathrm{C} / \mathrm{N}$ ratios of the organic-carbon-poor sediments should be interpreted very cautiously because in organic-carbon-poor sediments the amount of inorganic nitrogen (fixed as ammonium ions in the interlayers of clay minerals, especially illite) may become a major portion of the total nitrogen, causing $\mathrm{C} / \mathrm{N}$ ratios that are too low (e.g., Müller, 1977). Furthermore, a quantitative estimation of the marine/ terrigenous proportions of the organic matter using $\mathrm{C} / \mathrm{N}$ ratios is more difficult because of the wide range in $\mathrm{C} / \mathrm{N}$ ratios of terrigenous plant material (e.g., Scheffer and Schachtschabel, 1984). C/N ratios of seagrass (Zostera), which is a major organic-carbon source in the Santa Barbara Basin, are high (around 15), whereas the HI values of seagrass are also relatively high (around $150 \mathrm{mgHC} / \mathrm{gC}$ ) (Stein, unpubl. data). These factors may partly explain the disagreements between $\mathrm{C} / \mathrm{N}$ and $\mathrm{HI}$ data in relation to the estimates of the terrestrialmarine balance in organic-matter source. Furthermore, the HI values are supported by the $n$-alkane data (see below). Thus, in the discussion we mainly used $\mathrm{HI}$ values as source indicator.

\section{DISCUSSION}

\section{Sources of Organic Carbon in the Santa Barbara Basin}

One of the characteristics of Holocene sediments from the Santa Barbara Basin is the high organic-carbon content ranging in general between $1 \%$ and $5 \%$ (e.g., Heath et al., 1977; Schimmelmann and Kastner, 1993). Based on detailed sedimentological, geochemical, and micropaleontological investigations of piston cores representing the last hundreds to thousands of years, the organic-carbon deposition is largely controlled by environmental and biological factors, such as terrigenous sediment supply, surface-water productivity, bacterial mat growth, and oxygenation of bottom waters (e.g., Fleischer, 1972; Soutar and Crill, 1977; Lange et al., 1990; Reimers et al., 1990; Schimmelmann et al., 1990; Schimmelmann and Kastner, 1993). Seasonal variations of these processes result in the finely laminated (varved) sediments typical for the Holocene central Santa Barbara Basin. According to Schimmelmann and Tegner (1991), the major sources of organic matter of the Holocene Santa Barbara Basin sediments are phytoplankton-derived biomass, macroalgal biomass from the kelp forests surrounding the Basin (North, 1971), terrigenous biomass, and redeposited fossil organic carbon. The latter two sources are of secondary importance and restricted to a few unusual flood and oil spill events. This identification of different organic-carbon sources is derived from $\delta^{13} \mathrm{C}_{\text {org }}$ values. Modern phytoplankton productivity in the southern California Bight area is about $150-300 \mathrm{gC} \mathrm{m}^{-2} \mathrm{y}^{-1}$ (Eppley and Holm-Hansen, 1986); the modern kelp (Macrocystis spp.) production is estimated to be about $800-1000 \mathrm{gC} \mathrm{m}^{-2} \mathrm{y}^{-1}$ (Mann, 1982). For estimates of the importance of either of these organic-carbon sources in the Santa Barbara Basin, however, one also has to consider that the area occupied by kelp forests is an order of magnitude smaller than the area available for phytoplankton production (Schimmelmann and Tegner, 1991). A further significant source of organic matter should also be the production of biomass by bacteria (Soutar and Crill, 1977; Reimers et al., 1990).

The TOC values of the major lithologies of Site 893 are in the same range as those determined in sediment samples from piston cores, with highest values in the laminated intervals ( $1 \%$ to $4.5 \%$; Table 1; Fig. 3). Based on the organic-carbon data, four different sedi- 
Table 1. Summary table of Hole 893A data.

\begin{tabular}{|c|c|c|c|c|c|c|c|c|c|c|c|c|c|c|c|c|c|c|}
\hline Core & $\mathrm{Sec}$ & Top & Depth & Depth-cor & $\begin{array}{l}\text { Age } \\
\text { (ka) }\end{array}$ & TC & TOC & $\mathrm{CaCO}_{3}$ & $\mathrm{~N}$-tot & TOC & SI & S2 & S3 & Tmax & $\mathrm{HI}$ & OI & $\mathrm{C} / \mathrm{N}$ & Remarks \\
\hline 1 & 1 & 10 & 0.10 & 0.10 & 0.046 & 3.42 & 3.09 & 2.7 & 0.33 & 3.18 & 0.88 & 3.98 & 5.70 & 417 & 129 & 185 & 9.4 & \\
\hline 1 & i & 31 & 0.31 & 0.31 & 0.153 & 4.44 & 4.38 & 0.5 & 0.43 & 4.40 & 1.24 & 5.46 & 6.07 & 414 & 125 & 139 & 10.2 & \\
\hline i & i & 48 & 0.48 & 0.48 & 0.243 & 4.00 & 4.50 & & 0.38 & 4.40 & 1.02 & 4.99 & 5.42 & 413 & & & & \\
\hline 1 & 1 & 70 & 0.70 & 0.70 & 0.362 & 3.84 & 3.29 & 4.6 & 0.37 & 3.45 & 0.83 & 4.78 & 5.43 & 419 & 145 & 165 & 8.9 & \\
\hline i & 1 & 90 & 0.90 & 0.90 & 0.472 & 4.55 & 3.81 & 6.2 & 0.43 & 4.06 & 0.95 & 5.46 & 5.90 & 415 & 143 & 155 & $\begin{array}{l}0.93 \\
8.9\end{array}$ & \\
\hline i & i & 110 & 1.10 & 1.10 & 0.584 & 4.38 & 3.48 & 7.5 & 0.40 & 3.76 & 1.02 & 5.34 & 5.39 & 415 & 153 & 155 & 8.7 & \\
\hline 1 & i & 130 & 1.30 & 1.30 & 0.697 & 4.10 & 3,36 & 6.1 & 0.36 & 3.58 & 1.02 & 4.90 & 5.64 & 412 & 146 & 168 & 9.3 & \\
\hline i & i & 149 & 1.49 & 1.49 & 0.805 & & & & & 1.75 & 0.25 & 0.83 & 2.30 & 414 & 47 & 131 & & gray bed \\
\hline 1 & 2 & 20 & 1.70 & 1.68 & 0.914 & 3.31 & 2.90 & 3.4 & 0.31 & 3.00 & 0.69 & 3.66 & 4.18 & 416 & 126 & 144 & 9.4 & \\
\hline i & 2 & 40 & 1.90 & 1.88 & 1.030 & 4.97 & 3.31 & 13.9 & 0.42 & 3.84 & 1.06 & 5.65 & 5.64 & 416 & 171 & 170 & 7.9 & \\
\hline 1 & 2 & 61 & 2.11 & 2.09 & 1.152 & 2.64 & 2.14 & 4.2 & 0.23 & 2.23 & 0.40 & 2.01 & 3.27 & 418 & 94 & 153 & 9.3 & gray bed \\
\hline i & 2 & 80 & 2.30 & 2.28 & 1.263 & 4.47 & 3.36 & 9.3 & 0.36 & 3.70 & 1.11 & 5.68 & 6.05 & 415 & 169 & 180 & 9.3 & \\
\hline 1 & 2 & 100 & 2.50 & 2.48 & 1.381 & 4.76 & 3.43 & 11.0 & 0.39 & 3.86 & 0.98 & 5.78 & 6.34 & 413 & 168 & 185 & 8.8 & \\
\hline 1 & 2 & 120 & 2.70 & 2.68 & $\begin{array}{l}1.499 \\
\text {. }\end{array}$ & 4.27 & 2.95 & 11.0 & 0.37 & 3.31 & 0.96 & 5.08 & 5.39 & 410 & 172 & 183 & 8.0 & \\
\hline 1 & 2 & 140 & 2.90 & 2.88 & $\begin{array}{l}1.617 \\
\end{array}$ & 3.25 & 2.82 & 3.6 & 0.30 & 2.92 & 0.67 & 3.68 & 3.87 & 408 & 131 & 137 & 9.4 & \\
\hline 1 & 3 & $\begin{array}{r}140 \\
10\end{array}$ & 3.12 & $\begin{array}{l}.808 \\
3.09\end{array}$ & $\begin{array}{l}1.017 \\
1.743\end{array}$ & 4.15 & 2.74 & 11.7 & 0.30 & 3.11 & 0.79 & 4.63 & 4.91 & 418 & $\begin{array}{l}169 \\
169\end{array}$ & 179 & 9.1 & \\
\hline 1 & 3 & 30 & 3.32 & 3.29 & $\begin{array}{l}1.862 \\
\text {. }\end{array}$ & 1.73 & 1.60 & 1.0 & 0.19 & $\begin{array}{l}1.62 \\
1.62\end{array}$ & 0.14 & 0.72 & 2.58 & 412 & 45 & 161 & 8.4 & gray bed \\
\hline 1 & 3 & 48 & 3.50 & 3.47 & $\begin{array}{l}1.970 \\
\text {. }\end{array}$ & 3.28 & 2.62 & 5.5 & 0.31 & 2.77 & 0.70 & 3.80 & 4.02 & 412 & 145 & 153 & 8.5 & gray oed \\
\hline 1 & 3 & 70 & 3.72 & 3.69 & 2.103 & 4.03 & 2.98 & 8.7 & 0.34 & 3.27 & 1.01 & 4.56 & 5.08 & 415 & 153 & 170 & 8.8 & \\
\hline i & 3 & 90 & 3.92 & 3.89 & 2.224 & 3.66 & 2.68 & 8.1 & 0.32 & 2.92 & 0.63 & 3.23 & 5.41 & 411 & 121 & 202 & 8.4 & \\
\hline i & 3 & 110 & 4.12 & 4.09 & 2.345 & 3.05 & 2.33 & 6.0 & 0.27 & 2.48 & 0.48 & 2.46 & 3.96 & 419 & 105 & 170 & 8.6 & \\
\hline i & 3 & 130 & 4.32 & 4.29 & 2.466 & 4.03 & & & 0.28 & & 0.71 & 4.29 & 4.80 & 411 & & & & \\
\hline i & 3 & 149 & 4.51 & 4.48 & 2.582 & 4.00 & 2.92 & 9.0 & 0.34 & 3.21 & 0.82 & 4.17 & 5.51 & 410 & 143 & 189 & 8.6 & \\
\hline i & 4 & 19 & 4.71 & 4.69 & 2.711 & 3.95 & 2.05 & 15.8 & 0.36 & 2.43 & 0.72 & 3.96 & 4.82 & 414 & 194 & 236 & 5.6 & \\
\hline i & 4 & 41 & 4.93 & 4.91 & 2.846 & 1.63 & & & 0.16 & & 0.12 & 0.70 & 1.74 & 424 & & & & \\
\hline 1 & 4 & 60 & 5.12 & 5.10 & 2.962 & 2.12 & 1.80 & 2.6 & 0.21 & 1.85 & 0.16 & 0.96 & 3.33 & 414 & 53 & 185 & 8.6 & gray bed \\
\hline i & 4 & 80 & 5.32 & 5.30 & 3.085 & 3.09 & 2.32 & 6.4 & 0.27 & 2.48 & 0.35 & 2.32 & 4.01 & 419 & 100 & 173 & 8.6 & \\
\hline i & 4 & 99 & 5.51 & 5.49 & 3.203 & 3.23 & & & & & 0.55 & 3.27 & 4.00 & 411 & & & & \\
\hline 1 & 4 & 120 & 5.72 & 5.70 & 3.333 & 1.87 & & & 0.20 & & 0.17 & 0.80 & 2.60 & 417 & & & & \\
\hline 1 & 4 & 140 & 5.92 & 5.88 & 3.444 & $\begin{array}{l}1.69 \\
1.69\end{array}$ & 1.54 & 1.2 & 0.19 & 1.56 & 0.13 & $\begin{array}{l}0.80 \\
0.84\end{array}$ & 2.02 & 422 & 55 & 131 & 8.1 & gray bed \\
\hline 1 & 5 & 10 & 6.12 & 6.08 & 3.568 & 1.79 & 1.29 & 4.1 & 0.16 & 1.35 & 0.14 & 0.79 & 2.11 & 416 & 61 & 164 & 8.1 & gray bed \\
\hline i & 5 & 27 & 6.29 & 6.25 & 3.674 & 3.86 & 2.95 & 7.6 & 0.35 & 3.19 & 0.68 & 3.53 & 5.15 & 410 & 120 & 175 & 8.4 & \\
\hline 2 & 1 & 10 & 6.60 & 6.60 & $\begin{array}{l}3.092 \\
\end{array}$ & $\begin{array}{l}3.00 \\
1.54\end{array}$ & 2.93 & & 0.10 & 3.19 & 0.18 & 0.85 & 1.53 & 414 & & & & gray bed \\
\hline 2 & i & 30 & 6.80 & 6.79 & 4.011 & 3.61 & & & 0.28 & & 0.59 & 3.62 & 4.16 & $\begin{array}{l}144 \\
415\end{array}$ & & & & gray bea \\
\hline 2 & i & 50 & 7.00 & 6.99 & 4.136 & 5.76 & 2.09 & & 0.41 & 3.01 & 0.56 & 3.49 & 4.85 & 418 & 167 & 232 & 5.1 & \\
\hline 2 & i & 70 & 7.20 & 7.18 & 4.255 & 3.33 & 2.54 & 6.6 & 0.24 & 2.72 & 0.52 & 4.66 & 3.76 & 422 & 184 & 148 & 10.6 & \\
\hline 2 & i & 90 & 7.40 & 7.39 & 4.387 & 3.70 & & & 0.28 & & 0.62 & 3.37 & 4.76 & 409 & & & & \\
\hline 2 & i & 110 & 7.60 & 7.59 & 4.513 & 3.61 & 2.58 & 8.6 & 0.27 & 2.82 & 0.57 & 3.17 & 4.79 & 415 & 123 & 186 & 9.6 & \\
\hline 2 & 1 & 130 & 7.80 & 7.79 & 4.639 & 1.41 & & & 0.12 & & 0.11 & 0.56 & 1.12 & 421 & & & & gray bed \\
\hline 2 & 1 & 150 & 8.00 & 7.99 & 4.766 & 4.31 & 3.07 & 10.4 & 0.30 & 3.42 & 0.81 & 4.43 & 4.96 & 413 & 144 & 162 & 10.2 & \\
\hline 2 & 2 & 0 & 8.04 & 8.00 & 4.772 & 4.26 & 3.06 & 10.0 & 0.31 & 3.40 & 0.76 & 4.08 & 5.19 & 411 & 133 & 170 & 9.9 & \\
\hline 2 & 2 & 20 & 8.24 & 8.20 & 4.898 & 3.90 & 2.71 & 9.9 & 0.27 & 3.01 & 0.69 & 3.78 & 4.65 & 414 & 139 & 171 & 10.0 & \\
\hline 2 & 2 & 40 & 8.44 & $\begin{array}{l}8.20 \\
8.40\end{array}$ & $\begin{array}{l}.0 .028 \\
5.025\end{array}$ & 4.18 & 3.16 & 8.5 & 0.32 & $\begin{array}{l}3.01 \\
3.46\end{array}$ & 0.83 & $\begin{array}{l}4.76 \\
\end{array}$ & $\begin{array}{l}4.03 \\
4.75\end{array}$ & $\begin{array}{l}114 \\
412\end{array}$ & 151 & 150 & 9.9 & \\
\hline 2 & 2 & $\begin{array}{l}40 \\
60\end{array}$ & 8.64 & $\begin{array}{l}8.40 \\
8.60\end{array}$ & 5.152 & 3.48 & 2.51 & 8.0 & 0.25 & $\begin{array}{l}2.40 \\
2.73\end{array}$ & $\begin{array}{l}0.83 \\
0.57\end{array}$ & 2.99 & 3.70 & $\begin{array}{l}112 \\
410\end{array}$ & 119 & 147 & $\begin{array}{r}9.9 \\
10.0\end{array}$ & \\
\hline 2 & 2 & 80 & 8.84 & 8.76 & 5.253 & 4.01 & 2.91 & 9.1 & 0.32 & 3.20 & 0.87 & 6.26 & 4.03 & 413 & 215 & 138 & 9.1 & \\
\hline 2 & 2 & 100 & 9.04 & 8.96 & 5.380 & 3.69 & 2.65 & 8.7 & 0.27 & 2.90 & 0.70 & 3.75 & 4.10 & 405 & 142 & 155 & 9.8 & \\
\hline 2 & 2 & 120 & 9.24 & 9.16 & 5.508 & 2.89 & 2.20 & $\begin{array}{l}5.1 \\
5.8\end{array}$ & 0.27 & 2.33 & 0.45 & 3.42 & 3.33 & 416 & 156 & 151 & 8.1 & \\
\hline 2 & 2 & 140 & 9.44 & 9.36 & 5.635 & 3.65 & 2.54 & 9.2 & 0.26 & 2.80 & 0.57 & 2.90 & 4.48 & 405 & 114 & 176 & 9.8 & \\
\hline 2 & 3 & 10 & 9.64 & 9.54 & 5.750 & 3.31 & & & 0.24 & & 0.56 & 2.77 & 3.80 & 408 & & & & \\
\hline 2 & 3 & 30 & 9.84 & 9.74 & 5.878 & 3.40 & 2.35 & 8.8 & 0.25 & 2.57 & 0.51 & 3.92 & 4.16 & 416 & 167 & 177 & 9.4 & \\
\hline 2 & 3 & 50 & 10.04 & 9.92 & 5.993 & 3.27 & 2.15 & 9.3 & 0.23 & 2.37 & 0.44 & 2.25 & 3.94 & 405 & 105 & 183 & 9.3 & \\
\hline 2 & 3 & 70 & 10.24 & 10.12 & 6.121 & 3.02 & 2.09 & 7.7 & 0.24 & 2.26 & 0.46 & 3.49 & 3.25 & 415 & 167 & 156 & 8.7 & \\
\hline 2 & 3 & 90 & 10.44 & 10.32 & 6.249 & 3.40 & 2.28 & 9.3 & 0.23 & 2.51 & 0.78 & 3.07 & 4.41 & 409 & 135 & 194 & 9.9 & \\
\hline 2 & 3 & 110 & 10.64 & 10.52 & 6.377 & 3.43 & 2.23 & 10.0 & 0.23 & 2.48 & 0.49 & 2.83 & 4.13 & 410 & 127 & 185 & 9.7 & \\
\hline 2 & 3 & 129 & 10.83 & 10.67 & 6.474 & 3.33 & 2.37 & 7.9 & 0.23 & 2.58 & 0.48 & 2.58 & 4.08 & 411 & 109 & 172 & 10.3 & \\
\hline 2 & 3 & 150 & 11.04 & 10.86 & $\begin{array}{l}0.474 \\
6.596\end{array}$ & 2.21 & & & 0.18 & & $\begin{array}{l}0.48 \\
0.24\end{array}$ & 1.22 & $\begin{array}{l}4.08 \\
2.74\end{array}$ & 414 & & & 10.8 & \\
\hline 2 & 4 & 0 & 11.05 & 10.86 & 6.596 & 1.37 & 1.15 & 1.8 & 0.14 & 1.17 & 0.12 & 0.60 & 1.27 & 417 & 52 & 110 & 8.2 & gray bed \\
\hline 2 & 4 & 20 & 11.25 & 11.04 & 6.712 & 3.04 & 2.22 & $\begin{array}{l}6.8 \\
6.8\end{array}$ & 0.22 & 2.38 & 0.42 & 2.26 & 3.93 & 410 & 102 & 177 & 10.1 & \\
\hline 2 & 4 & 40 & 11.45 & 11.22 & 6.828 & 3.38 & & & 0.24 & & 0.50 & 2.76 & 3.71 & 411 & & & & \\
\hline
\end{tabular}

Notes: Depth (mbsf), void-corrected depth (after Rack and Merrill, this volume); age (Ingram and Kennett, this volume; Kennett, this volume); total carbon, total organic carbon, carbonate, and total nitrogen in wt\% of bulk sediment; total organic carbon values of the carbonate-free sample ( $\left.=\mathrm{TOC}^{\prime}\right)$; Rock-Eval parameters: $\mathrm{S} 1$ (mgHC/gSediment), $\mathrm{S} 2$ (mgHC/gRock), $\mathrm{S} 3$ (mgCO $2 / \mathrm{gSediment}$ ), Tmax $\left({ }^{\circ} \mathrm{C}\right)$, hydrogen index (mgHC/gTOC), and oxygen index (mgCO $/$ gTOC); C/N ratios. Samples from sand beds and gray beds are indicated.

Only the first page of this table is reproduced here. The entire table appears on the CD-ROM (back pocket). 
Table 2. AMS ${ }^{14} \mathrm{C}$ chronology, linear sedimentation rates (LSR), mean TOC values, dry density values (DD), and accumulation rates of bulk sediment (BulkAccRate) and total organic carbon (TOC-AccRate) for the past 30,000 years at Hole 893A.

\begin{tabular}{|c|c|c|c|c|c|c|c|c|}
\hline $\begin{array}{l}\text { Depth } \\
\text { (mbst) }\end{array}$ & $\begin{array}{l}\text { Difference } \\
\text { (m) }\end{array}$ & $\begin{array}{c}\text { Age } \\
\text { (yr BP) }\end{array}$ & $\begin{array}{c}\text { Difference } \\
(\mathrm{yr})\end{array}$ & $\begin{array}{c}\text { LSR } \\
\text { (cm/k.y.) }\end{array}$ & $\begin{array}{c}\text { Mean DD } \\
\left(\mathrm{g} / \mathrm{cm}^{3}\right)\end{array}$ & $\begin{array}{c}\text { Mean TOC } \\
(\%)\end{array}$ & $\begin{array}{c}\text { Bulk acc } \\
\text { rate } \\
\left(\mathrm{g} / \mathrm{cm}^{2} / \mathrm{k} . \mathrm{y} .\right)\end{array}$ & $\begin{array}{c}\text { TOC-acc } \\
\text { rate } \\
\left(\mathrm{gC} / \mathrm{cm}^{2} / \mathrm{k} . \mathrm{y} .\right)\end{array}$ \\
\hline 0 & & 0 & & & & & & \\
\hline 360 & 3.62 & 1670 & 1670 & 217 & 0.5 & 3 & 108 & 3.35 \\
\hline 3.62 & 2.05 & 1.670 & 1110 & 185 & 0.61 & 2.51 & 113 & 2.83 \\
\hline 5.67 & 3.04 & 2,780 & 3410 & 89 & 0.69 & 2.5 & 61 & 1.53 \\
\hline 8.71 & 5.26 & 6,190 & 3150 & 167 & 0.78 & 2.19 & 130 & 285 \\
\hline 13.97 & 3.02 & 9,340 & 1130 & 267 & 0.72 & 1.82 & 192 & 3.5 \\
\hline 16.99 & 0.61 & 10,470 & 590 & 103 & 0.8 & 1.89 & 82 & 1.56 \\
\hline 17.6 & 1.15 & 11,060 & 760 & 151 & 0.86 & 1.73 & 130 & 2.25 \\
\hline 18.15 & 1.64 & 11,820 & 1151 & 142 & 0.8 & 1.9 & 114 & 2.16 \\
\hline 2104 & 1.55 & מדונ, & 465 & 333 & 0.76 & 1.63 & 253 & 4.12 \\
\hline 21.94 & 2.18 & 8,436 & 975 & 224 & 0.83 & 1.6 & 186 & 2.98 \\
\hline 2558 & 1.46 & 16 & 1856 & 79 & 0.84 & 1.75 & 66 & 1.16 \\
\hline 29.61 & 4.03 & $\begin{array}{l}16,26 / \\
18,254\end{array}$ & 1987 & 203 & 0.94 & 1.63 & 191 & 3.11 \\
\hline 250.01 & 1.91 & 10,234 & 2538 & 75 & 0.92 & 1.76 & 69 & 1.21 \\
\hline 43.17 & 11.65 & 28.896 & 8104 & 144 & 0.87 & 1.76 & 125 & 2.21 \\
\hline
\end{tabular}

Note: LSR from Ingram and Kennett, this volume.

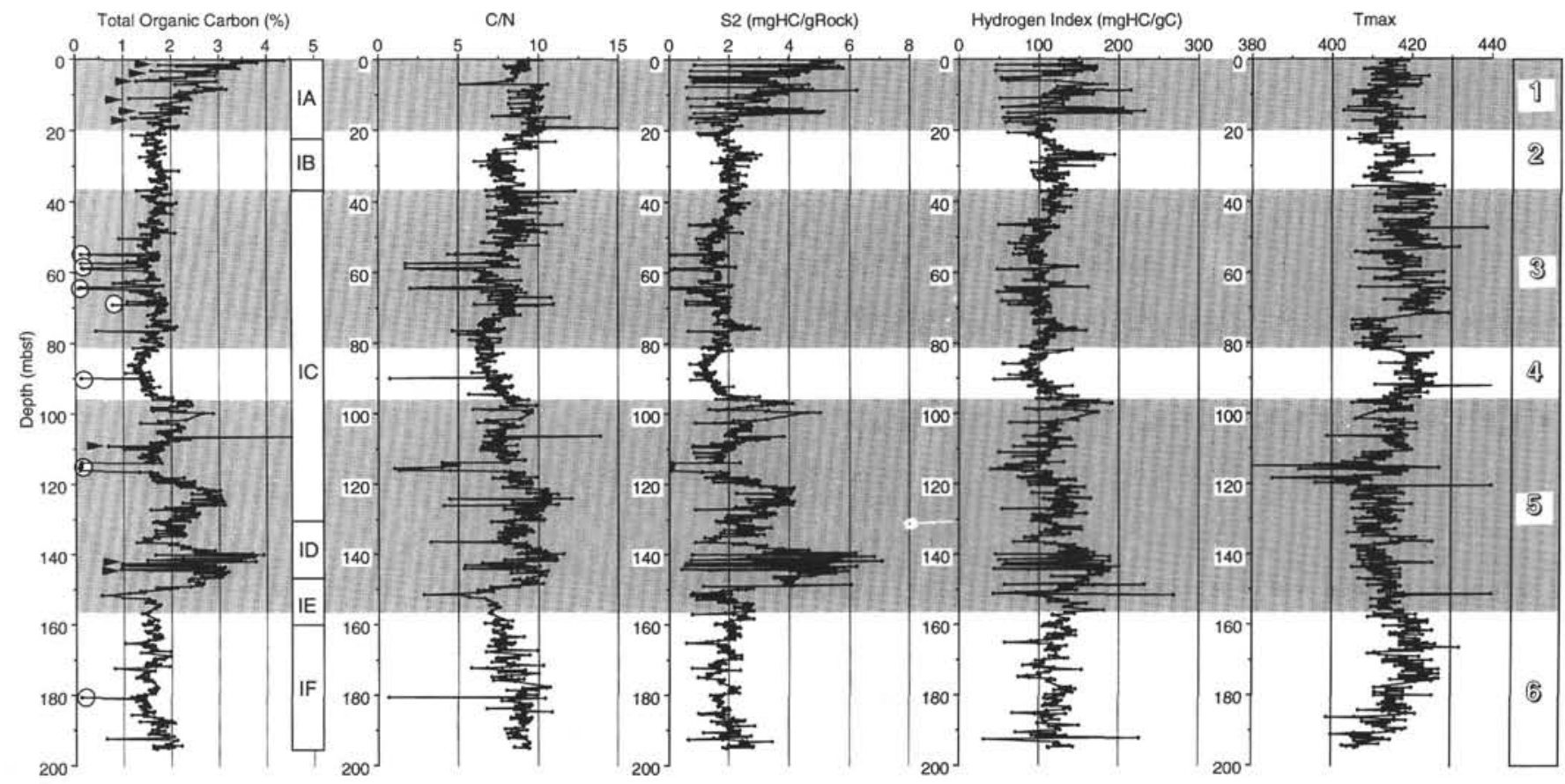

Figure 3. Total organic carbon (wt\%), total organic carbon/total nitrogen $(\mathrm{C} / \mathrm{N})$ ratio, $\mathrm{S} 2(\mathrm{mgHC} / \mathrm{gC})$, Hydrogen Index ( $\mathrm{mgHC} / \mathrm{gC})$, and Tmax values of Hole 893A sediments vs. void-corrected depth values. IA to IF mark lithologic subunits, encircled data points mark sand beds, and black arrows mark gray beds (after Kennett, Baldauf, et al., 1994). Open numbers 1 to 6 indicate oxygen-isotope stages (after Ingram and Kennett, this volume).

ment types with different organic-carbon sources can be distinguished (Table 3):

1. In the olive laminated sediments characterized by TOC values between $1.5 \%$ and $4.5 \%$ and $\mathrm{HI}$ values of 100 to $250 \mathrm{mgHC} /$ $\mathrm{gC}$, the organic matter is a mixed marine/terrigenous type with a dominance of the marine proportions in the hydrogen-rich intervals. Increased phytoplankton productivity and/or increased preservation of marine organic matter under oxygendepleted bottom-water conditions may have caused the marine-organic-carbon enrichment (see below). High amounts of diatoms and abundant Chaetoceras resting spores (PI. 1) also 
support a high-surface-water-productivity environment. Intervals with reduced $\mathrm{HI}$ values point to increased supply of terrigenous material.

2. The non-laminated homogeneous, and partly bioturbated intervals display lower TOC values of $1.2 \%$ to $2.5 \%$ and $\mathrm{HI}$ values of 50 to $150 \mathrm{mgHC} / \mathrm{gC}$. Here, the terrigenous organic-carbon proportion is dominant, although marine phytoplankton-derived material may be still present. Increased supply of terrigenous material and/or reduced preservation/production of marine organic matter can explain this observation. The bioturbation and the absence of laminations suggest oxic bottom waters, either caused by additions of more oxygenated seawater to the deep basin or reduced flux of organic matter and, thus, reduced oxygen consumption during decomposition process of the organic matter.

3. In the gray clayey silt to silty clay, almost microfossil-free beds (Pl. 1, Fig. 1), the TOC values as well as the $\mathrm{HI}$ indices are significantly lower, generally ranging from $0.9 \%$ to $1.8 \%$ and 40 to $90 \mathrm{mgHC} / \mathrm{gC}$, respectively (Table 3 ; Fig. 3). That means, the organic matter certainly has a major terrigenous source. A major proportion of terrigenous organic matter in the gray beds investigated in piston cores from the Santa Barbara $\mathrm{Basin}$ is also indicated by the relatively low mean $\delta^{13} \mathrm{C}_{\text {org }}$ values of $-23.4 \%$ (Schimmelmann and Tegner, 1991). Based on box and piston cores studies, the gray beds correlate with historical flood and storm events in California and are interpreted as deposits of low-density turbidity currents or settling of flood-related nepheloid suspensions (Fleischer, 1972; Thornton, 1984). During flood years, the Ventura River and the Santa Clara River (Fig. 1) may transport large amounts of suspension (rich in terrigenous organic matter) to the shelf/upper slope of the Santa Barbara Basin (Drake et al., 1972). The origin of the turbiditic flood deposits is thus very probably the upper slope close to the continental shoreline in the north, where terrigenous organic matter is more concentrated.

4. In the coarse-grained sand beds, which are composed of up to $86 \%$ quartz-rich sand fraction (Stein, this volume), very low TOC contents of $0.1 \%$ to $0.3 \%$ and $\mathrm{HI}$ values of 40 to 80

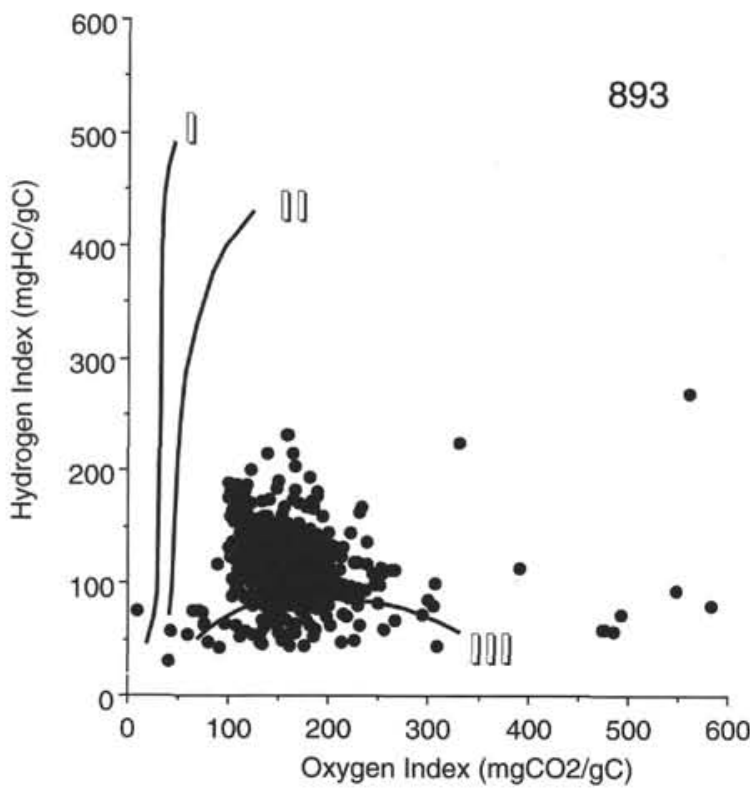

Figure 4. Hydrogen Index vs. Oxygen Index ("van-Krevelen-type") diagram of Hole 893A sediments. Roman numbers mark different kerogen types: I and $\mathrm{II}=$ marine, $\mathrm{III}=$ terrigenous organic matter (classification after Espitalié et al., 1977; Peters, 1986).
$\mathrm{mgHC} / \mathrm{gC}$ were determined. Although the $\mathrm{HI}$ values of these organic-carbon-poor sediments have to be interpreted with extreme caution, a terrigenous source of the organic matter is very probable. These normally graded or massive sand beds with sharp bases are considered to be turbidites (Kennett, Baldauf, et al., 1994). The source of the deposits including the organic matter is the coastal-near upper slope/shelf environment.

Gas chromatography and gas chromatography/mass spectrometry data generally support the Rock-Eval data. A dominance of longchain $\mathrm{C}_{29}$ and $\mathrm{C}_{31}$ in the $n$-alkane fraction (as indicator for terrestrial higher plant waxes) and major occurrences of steroles and ketones as well as the presence of significant amounts of the $\mathrm{C}_{17} n$-alkane (as indicators for marine organic matter) also indicate a mixed marine/terrigenous organic-carbon type to be characteristic in the major olive laminated as well as non-laminated lithologies (Fig. 5; Hinrichs, 1994; Hinrichs et al., this volume). Furthermore, the presence of specific hopenes and fernenes in the Site 893 sediments suggests bacterial biomass production (Hinrichs et al., this volume).

Estimates about the importance of fossil organic-carbon supply into the Santa Barbara Basin are still preliminary. A tar horizon at about 110 mbsf (Section 146-893A-12H-7) and a tar-saturated pebble-sized fragment of wood or charcoal (Kennett, Baldauf, et al., 1994) as well as a few single high Tmax values of about $440^{\circ} \mathrm{C}$ (Fig. 3) suggest occasional occurrences of more mature organic matter in the Site 893 sediments. In general, however, Tmax values of $<425^{\circ} \mathrm{C}$ point to dominantly immature organic matter throughout the entire section. Long-term trends in Tmax variations, on the other hand, may indicate some variations in maturity in the low-maturity range (see below).

To get more precise information about organic-carbon-type variations between the different major lithologies as well as between dark/light laminae, a detailed microscopic study of resin-embedded sediment sections from Site 893 is in progress (Stein, unpubl. data). Based on this data set, it will be possible to distinguish the different organic-carbon sources (i.e., phytoplankton, macroalgae, terrigenous plant debris; fossil organic matter) more accurately.

\section{Variations in Flux and Composition of the Organic Carbon and Climate Change}

To interpret the organic carbon variations through time and their relationship to global climate history, the depth scale was transferred into an age scale using the $\mathrm{AMS}^{14} \mathrm{C}$ chronology and oxygen-stableisotope stratigraphy of Ingram and Kennett (this volume) and Kennett (this volume). From Figure 6, it is obvious that the organic-carbon record correlates very well with oxygen-stable-isotope stages representing global climatic evolution (e.g., Martinson et al., 1987). Obvious long- and short-term variations in organic-carbon content may correspond to Milankovitch-type climate cycles and higher-frequency variations. The last full interglacial/glacial 100-k.y. cycle between the Stage 6/5 and Stage 2/1 transitions (i.e., Termination II and Termination I, respectively) is superimposed by cyclic variations with a period of about $20 \mathrm{k} . \mathrm{y}$. probably representing the precession cycle (Fig. 6). Higher-frequency variations of a few thousands of years up to seasonal variations are especially present in interglacial Stages 1,5a, and 5e (Figs. 3 and 6). Climate-controlled cycles on time scales of a few thousands of years (i.e., distinctly shorter than the Milankovitch orbital cycles) are also described from other parts of the world ocean (e.g., Bond and Lotti, 1995; Fronval et al., 1995; Stein et al., in press) and in the GRIP Ice Core (Dansgaard et al., 1993).

In general, glacial Stage 6 and Stages 4 to 2 are characterized by low TOC values, whereas during interglacials TOC was increased. Interglacial Stage 5 can be further subdivided into the warm interstadials $5 \mathrm{a}, 5 \mathrm{c}$, and $5 \mathrm{e}$ characterized by increased TOC contents, and 
Table 3. Different lithologies and their organic-carbon characteristics at Hole 893A.

\begin{tabular}{|c|c|c|c|c|c|c|}
\hline Lithology & Lith. subunit & Isotope stages & $\begin{array}{l}\text { TOC } \\
(\%)\end{array}$ & $\begin{array}{c}\mathrm{HI} \\
(\mathrm{mgHC} / \mathrm{gC})\end{array}$ & Type of OC & Source \\
\hline $\begin{array}{l}\text { Laminated olive } \\
\text { intervals }\end{array}$ & IA. ID & 1. $5 \mathrm{e},(5 \mathrm{a})$ & 1.5 to 4.5 & 100 to 250 & Mixed (++ marine) & Phytoplankton, macroalgae?; terrigenous biomass \\
\hline $\begin{array}{l}\text { Non-laminated olive } \\
\text { intervals }\end{array}$ & IB, IC, IE, IF & $2,3,4,5$ b. $5 d, 6$ & 1.2 to 2.5 & 50 to 150 & Mixed (++ terrigenous) & Terrigenous biomass; phytoplankton, macroalgae? \\
\hline Thin gray beds & IA, ID & $5 e, 1$ & 0.9 to 1.8 & 40 to 90 & Terrigenous & Flood/turbidity deposits \\
\hline Sand beds & IC & $3,5 b$ & 0.1 to 0.3 & 40 to 80 & Terrigenous & Turbidites \\
\hline
\end{tabular}

Note: The hydrogen index values of the organic-carbon-poor sandy beds should be interpreted with major caution.

A

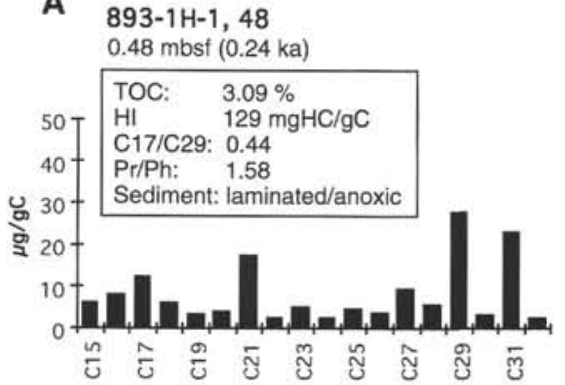

D

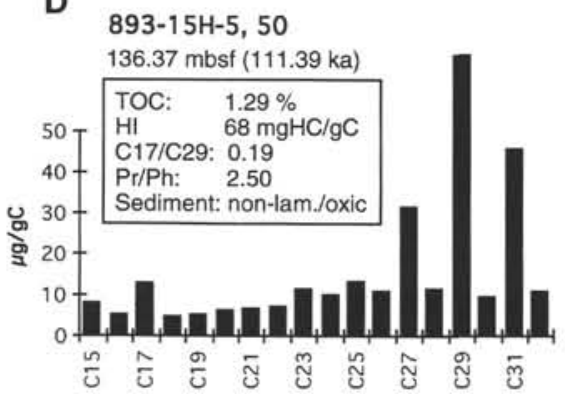

B

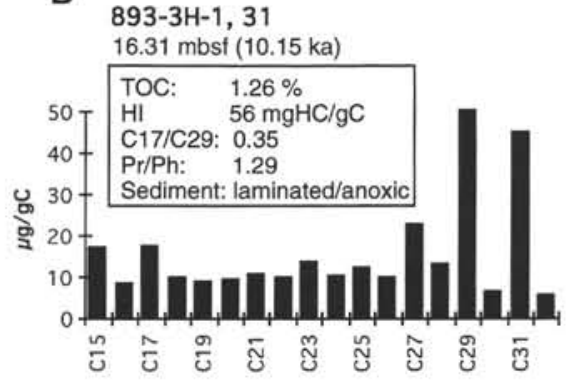

$\mathbf{E}$

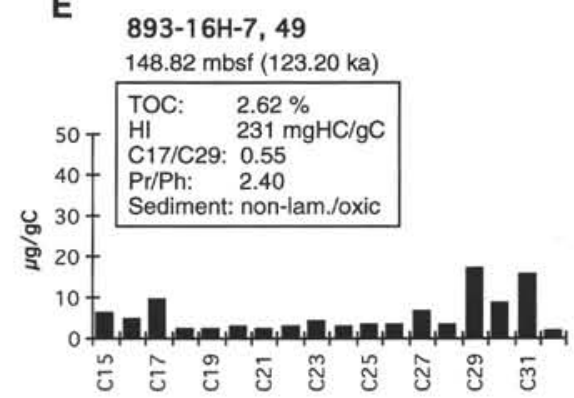

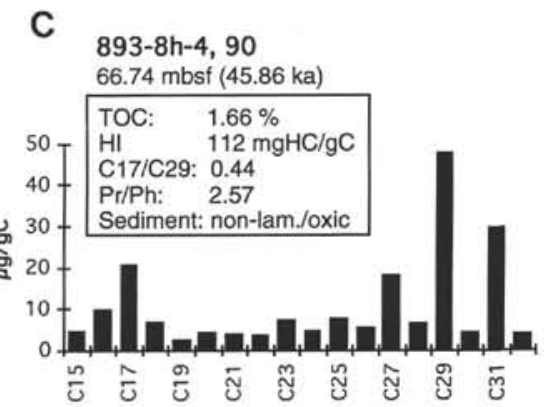

$\mathbf{F}$

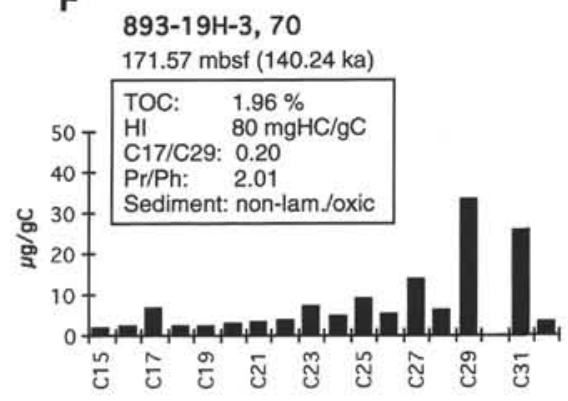

Figure 5. Distribution of $n$-alkanes $\left(\mathrm{C}_{15}-\mathrm{C}_{32}\right.$; in $\mu \mathrm{g}$ hydrocarbon per $\mathrm{g}$ total organic carbon) in six selected samples from laminated and non-laminated intervals. In addition, TOC and hydrogen index values, $\mathrm{C}_{17} / \mathrm{C}_{29}$ ratios, and pristane/phytane ratios are shown. (A) and (B) correspond to oxygen-isotope Stage 1 , (C) to Stage 3, (D) to substage 5d, (E) to substage 5e, and (F) to Stage 6.

cold interstadials $5 \mathrm{~b}$ and $5 \mathrm{~d}$ with reduced TOC contents. The absolute TOC maxima fall into Stage $5 \mathrm{e}$ and the uppermost Stage 1 (Holocene). According to the $\mathrm{HI}$ values, highest amounts of marine organic matter were preserved in the sediments of warm Stages $5 \mathrm{e}, 5 \mathrm{a}$, and 1 (Fig. 6). This is also supported by the $\mathrm{C}_{17} / \mathrm{C}_{29} n$-alkane ratio reaching highest values (indicative for a relative enrichment of the phytoplankton-derived $\mathrm{C}_{17} n$-alkane) in substage $5 \mathrm{e}$ and the upper Holocene (Fig. 5). A further peak of increased preservation of marine organic matter appears to occur within the middle part of Stage 2 near 17-18 ka (Fig. 6).

Because changes in organic-carbon concentrations can result from changes in both mineral components and organic-carbon content, the percentage values were transferred into mass accumulation rates (see methods). Using these accumulation rates, dilution effects can be excluded and the organic-carbon data interpreted in terms of changes in organic-carbon flux. Based on the average sedimentation rates according to the stratigraphic framework of Ingram and Kennett (this volume) and Kennett (this volume), flux rates of total organic carbon were calculated (Fig. 7). Because mean sedimentation rates were used, single TOC peaks should not be interpreted. Instead, the general trend is important. In general, the accumulation rates of total organic carbon vary between 1.5 and $6 \mathrm{gC} \mathrm{cm}^{-2} \mathrm{ky}^{-1}$. These values are similar to those described for modern coastal-upwelling high-produc- tivity environments (e.g., Peru upwelling: 1.3 to $6.3 \mathrm{gC} \mathrm{cm}^{-2} \mathrm{ky}^{-1}$; Reimers and Suess, 1983). Maximum organic-carbon fluxes were calculated for the interglacial Stages 5e and 1. Keeping in mind that in these intervals the source of the organic matter is dominantly marine, this suggests increased marine organic-carbon flux at those times. Abundant occurrences of diatoms (PI. 1) point to increased surface-water productivity. This increased surface-water productivity was probably controlled by the inflow of nutrient-rich California Current waters. On the other hand, major proportions of the organiccarbon accumulation rates calculated for the glacial Stage 6 and Stages 4-2 and the cold interstadials of Stage 5 may reflect the supply of terrigenous organic matter. The higher Tmax values of $420^{\circ} \mathrm{C}-$ $430^{\circ} \mathrm{C}$ (Fig. 3) may also point to a different terrigenous organic-carbon source during the upper glacial Stage 6, Stage 4, and most of Stage 3. During these times of lowered sea level, the inflow of the nutrient-rich California Current waters might have been reduced, resulting in decreased flux of marine organic carbon due to decreased surface-water productivity.

To get some ideas about the shorter-term variations in organiccarbon flux, accumulation rates were calculated for the last approximately 30,000 years (Table 2), using the $\mathrm{AMS}^{14} \mathrm{C}$ datings from Ingram and Kennett (this volume). According to the flux record shown in Figure 8, increased organic-carbon flux of $3-4 \mathrm{gC} \mathrm{cm}^{-2} \mathrm{ky}^{-1}$ occurs 


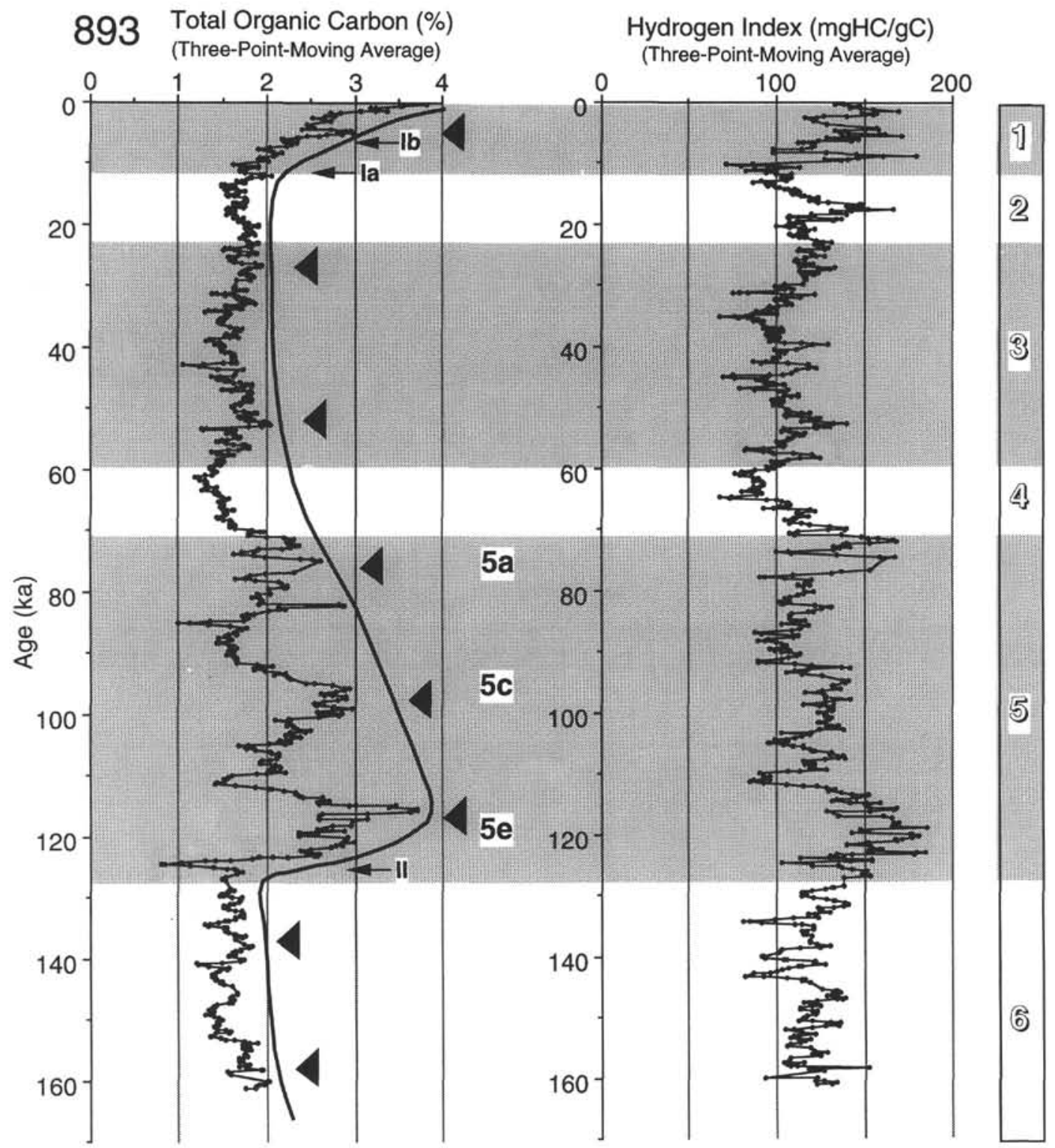

Figure 6. Total organic carbon and hydrogen index records vs. age, plotted as three-point-moving average. Data from gray beds and sandy beds (cf., Table 1 and Fig. 3) were not considered. Age scale according to Ingram and Kennett (this volume) and Kennett (this volume). Numbers 1, 2, 3, 5, 5a, 5c, 5e, and 6 mark oxygen-isotope stages, Ia and Ib and II mark terminations I and II. Black triangles indicate maxima in organic carbon.

between 18 and $16 \mathrm{ka}, 14$ and $13 \mathrm{ka}, 10$ and $6 \mathrm{ka}$, and during the last about $2.5 \mathrm{ka}$. Especially during the two youngest intervals of increased organic-carbon flux high $\mathrm{HI}$ values were recorded, indicating phases of increased marine organic-carbon fluxes. On the other hand, the two older maxima in organic-carbon flux more probably represent phases of increased flux of terrigenous organic matter (Fig. 8). During the Last Glacial Maximum (18-21 ka) and near 14-16 ka, distinct minima in organic carbon flux occur.

The variations in marine and terrigenous organic carbon fluxes can be explained by the model shown in Figure 9 (from Kennett, Baldauf, et al., 1994). During the Holocene, increased surface-water productivity triggered by the advection of nutrient-rich California Current waters into the Santa Barbara Basin, and the inflow of oxygen-depleted intermediate waters from the East Pacific have caused anoxic bottom-water, resulting in the preservation of varved-like laminations and large amounts of marine organic carbon. The surface-water productivity was probably also increased during the warm interstadials 5e and 5a, as indicated in the high (marine) organic car- bon flux. Anoxic conditions, however, did not occur throughout, because major parts of substages $5 \mathrm{e}$ and $5 \mathrm{a}$ are massive sediments, and varves are not preserved.

During glacial times (i.e., Stages 6 and 4 to 2 ) and cold interstadials $5 \mathrm{~d}$ and $5 \mathrm{~b}$, on the other hand, surface-water productivity was reduced (because of reduced advection of nutrient-rich California Current waters during times of lowered sea level) and the bottom-water conditions in the Santa Barbara Basin were more oxygenated. At those times of lowered sea level, the supply of terrigenous organic matter was probably increased also.

Although the pristane/phytane ratio should be used as paleoenvironmental indicator only with caution (ten Haven et al., 1987), these ratios may reflect the variations between oxic and anoxic bottom-water environment in the Santa Barbara Basin. The Holocene laminated sediments (probably deposited under anoxic conditions) show relatively low values, whereas the non-laminated sediments (deposited under oxic conditions) display distinctly higher pristane/phytane ratios (Fig. 5; Didyk et al., 1978). 


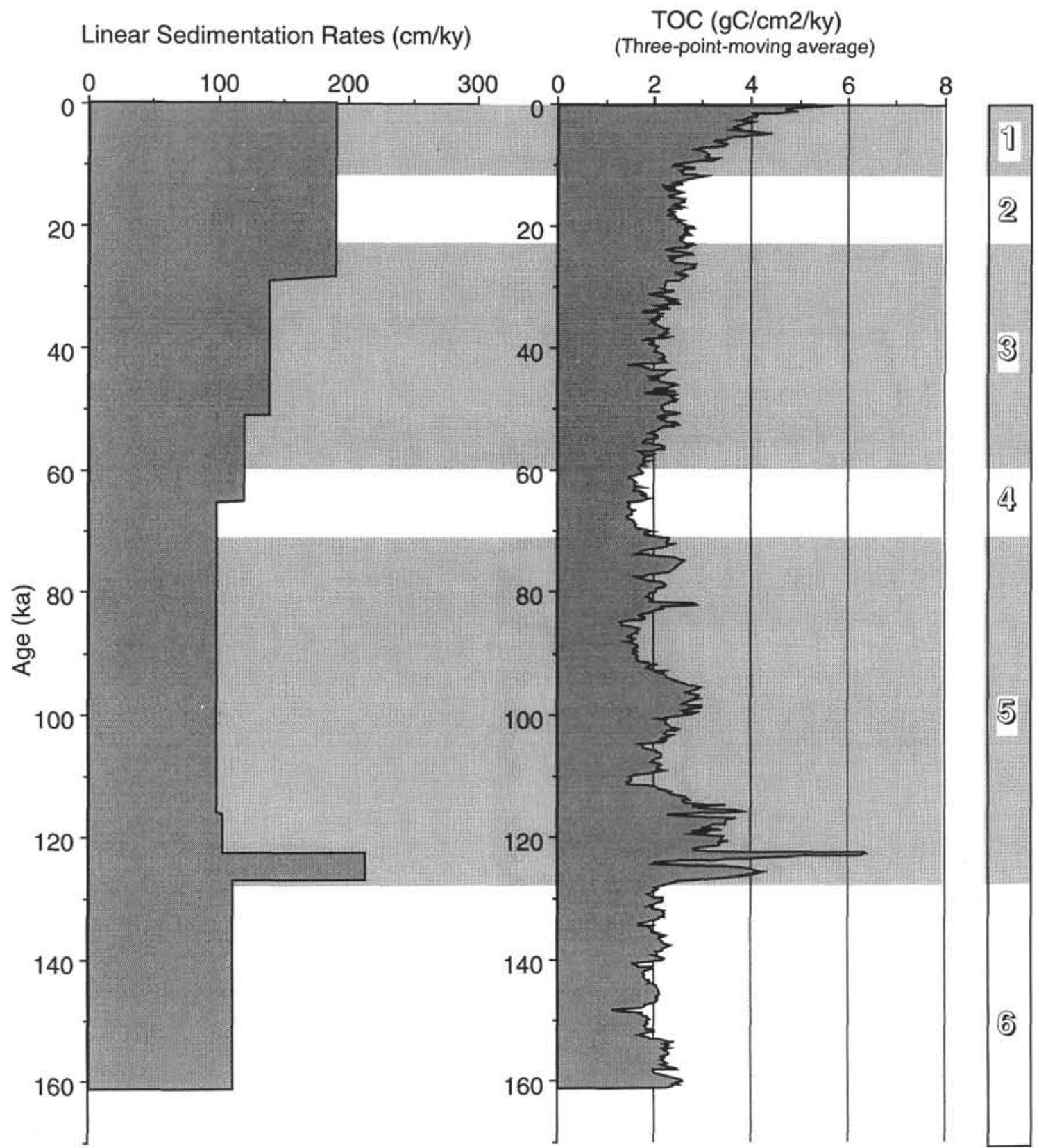

Figure 7. Linear sedimentation rates (after Ingram and Kennett, this volume; Kennett, this volume) and accumulation rates of total organic carbon vs. age at Hole 893A. Data from gray beds and sandy beds (cf., Table 1 and Fig. 3) were not considered.

\section{CONCLUSIONS}

The results of a high-resolution study of organic-carbon-variations in the Santa Barbara Basin through the past 160,000 years can be summarized as follows:

1. Based on the organic-carbon data, four different sediment types with different organic-carbon sources can be distinguished: (1) The organic matter of the finely laminated sediments with high-amplitude TOC variations of $1.5 \%$ to $4.5 \%$ is a mixed marine/terrigenous type with a dominance of the marine proportions, probably caused by increased phytoplankton productivity and/or increased preservation of marine organic matter under oxygen-depleted bottom-water conditions. Inter- vals with reduced $\mathrm{HI}$ values point to increased supply of terrigenous material. (2) In the non-laminated homogeneous sediments with lower TOC values of $1.2 \%$ to $2.5 \%$, terrigenous organic carbon is dominant, although marine phytoplankton-derived material may be still present. (3) The gray beds interpreted as flood or turbidity deposits, display low TOC contents $(0.9 \%-1.8 \%)$ of mainly terrigenous origin. (4) The sandy turbidites are characterized by minimum TOC values of $0.1 \%$ to $0.3 \%$.

2. Organic-carbon accumulation rates vary between 1.5 and $6 \mathrm{gC}$ $\mathrm{cm}^{-2} \mathrm{ky}^{-1}$, which are values similar to those recorded in modern upwelling high-productivity environments.

3. The organic-carbon data correlate with the global climate record and display Milankovitch-type as well as higher-fre- 


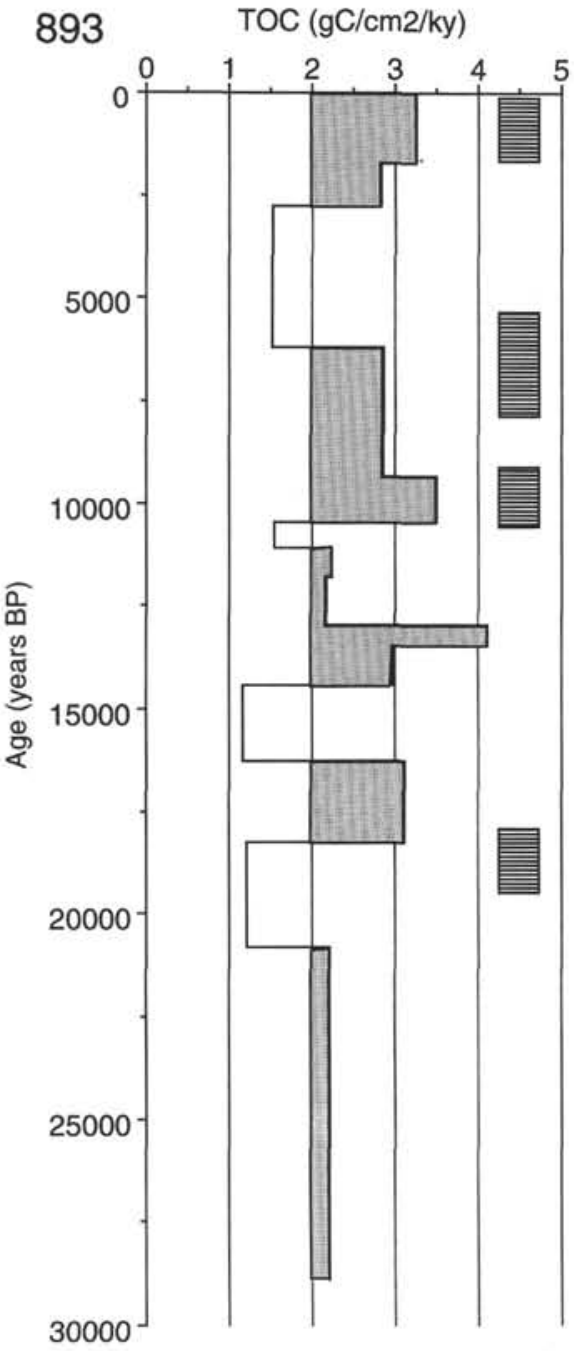

Figure 8. Mean accumulation rates of total organic carbon for the past 30,000 years, based on the $\mathrm{AMS}^{14} \mathrm{C}$ chronology of Ingram and Kennett (this volume); see Table 2 for data base. Hatched bars mark intervals of increased $\mathrm{HI}$ values, interpreted as intervals of increased accumulation/preservation of marine organic matter.

quency cyclicity. Glacial Stage 6,4 , and 2 as well as cold interstadials $5 \mathrm{~b}$ and $5 \mathrm{~d}$ are characterized by relatively low TOC values and a major terrigenous-organic-carbon signal. During interglacials $5 \mathrm{a}, 5 \mathrm{c}$, and, especially, $5 \mathrm{e}$ and the uppermost Stage 1 (Holocene), on the other hand, TOC contents were increased and major amounts of marine organic matter preserved, suggesting increased primary productivity. During the Holocene, suboxic to anoxic bottom-water conditions occurred as indicated by the preservation of varves throughout.

\section{ACKNOWLEDGMENTS}

We thank M. Apel, M. Seebeck, C. Schubert, M. Siebold, and R. Stax for technical assistance and data discussion. The reviews by Walter Dean and an anonymous reviewer are gratefully acknowledged. This is contribution No. 788 of the Alfred-Wegener-Institute for Polar and Marine Research, Bremerhaven.

\section{REFERENCES}

Baumgartner, T.R., Ferreira-Bartrina, V., and Soutar, A., 1991. Reconstruction of a twentieth century varve chronology from the central Gulf of California. In Dauphin, J.P., and Simoneit, B.R.T. (Eds.), The Gulf and Peninsular Province of the Californias. AAPG Mem., 47:603-616.

Bernhard, J.M., and Reimers, C.E., 1991. Benthic foraminiferal population fluctuations related to anoxia: Santa Barbara basin. Biogeochemistry, $15: 127-149$

Blumer, M., Guillard, R.R.L., and Chase, T., 1971. Hydrocarbons of marine phytoplankton. Mar. Biol., 8:183-189.

Bond, G.C., and Lotti, R., 1995. Iceberg discharges into the North Atlantic on millennial time scales during the last glaciation. Science, 267:10051010.

Bordovskiy, O.K., 1965. Accumulation and transformation of organic substances in marine sediment, 2. Sources of organic matter in marine basins. Mar. Geol., 3:5-31.

Dansgaard, W., Johnsen, S.J., Clausen, H.B., Dahl-Jensen, D., Grundestrup, N.S., Hammer, C.U., Hvidberg, C.S., Steffensen, J.P., Sveinbjörnsdottir, A.E., Jouzel, J., and Bond, G., 1993. Evidence for general instability of past climate from a 250-kyr ice-core record. Nature, 364:218-220.

Didyk, B.M., Simoneit, B.R.T., Brassell, S.C., and Eglinton, G., 1978. Organic geochemical indicators of palaeoenvironmental conditions of sedimentation. Nature, 272:216-222.

Drake, D.E., Kolpack, R.L., and Fischer, P.J., 1972. Sediment transport on the Santa Barbara-Oxnard shelf, Santa Barbara Channel, California. In Swift, D.J.P., Duane, D.B., and Pilkey, O.H. (Eds.), Shelf Sediment Transport: Process and Pattern: Stroudsburg, PA (Dowden, Hutchinson, and Ross), 307-331.

Dunbar, R.B., 1983. Stable isotope record of upwelling and climate from Santa Barbara Basin, California. In Thiede, J., and Suess, E. (Eds.), Coastal Upwelling, Its Sediment Record, Part B. Sedimentary Records of Ancient Coastal Upwelling: New York (Plenum), 217-246.

Eppley, R.W., and Holm-Hansen, O., 1986. Primary production in the Southern California Bight. In Eppley, R.W. (Ed.), Plankton Dynamics of the Southern California Bight. Lect. Notes Coastal Estuarine Stud., 15:176215.

Espitalié, J., Laporte, J.L., Leplat, P., Madec, M., Marquis, F., Paulet, J., and Boutefeu, A., 1977. Méthode rapide de caractérisation des roches mères, de leur potentiel pétrolier et de leur degré d'évolution. Rev. Inst. Fr. Pet., 32:23-42.

Farrimond, P., Poynter, J.G., and Eglinton, G., 1990. Molecular composition of sedimentary lipids off the Peru margin, Leg 112. In Suess, E., von Huene, R., et al., Proc. ODP, Sci. Results, 112: College Station, TX (Ocean Drilling Program), 539-546.

Fleischer, P., 1972. Mineralogy and sedimentation history, Santa Barbara Basin, California. J. Sediment. Petrol., 42:49-58.

Fronval, T., Jansen, E., Bloemendal, J., and Johnsen, S., 1995. Oceanic evidence for coherent fluctuations in Fennoscandian and Laurentide ice sheets on millennium timescales. Nature, 374: 443-446.

Heath, G.R., Moore, T.C., Jr., and Dauphin, J.P., 1977. Organic carbon in deep-sea sediments. In Andersen, N.R., and Malahoff, A. (Eds.), The Fate of Fossil Fuel $\mathrm{CO}_{2}$ in the Oceans: New York (Plenum), 605-625.

Heusser, L., 1978. Pollen in Santa Barbara Basin, California: a 12,000 year record. Geol. Soc. Am. Bull., 89:673-678.

Hickey, B.M., 1992. Circulation over the Santa Monica-San Pedro Basin and Shelf. In Small, L.F. (Ed.), Progress in Oceanography: Oxford (Pergamon Press), 30:37-115.

Hinrichs, K.-U., 1994. Pauschale und molekulare organisch-geochemische Untersuchungen an Sedimentproben aus dem Santa-Barbara-Becken, Kalifornien [M.S. thesis]. Oldenburg Univ., Oldenburg.

Kennedy, J.A., and Brassell, S.C., 1992a. Molecular records of twentieth century El-Niño events in laminated sediments from the Santa Barbara basin. Nature, 357:62-64.

1992b. Molecular stratigraphy of the Santa Barbara basin: comparison with historical records of annual climate change. Org. Geochem., 19:235-244.

Kennett, J.P., Baldauf, J.G., et al., 1994. Proc. ODP, Init. Repts., 146 (Pt. 2): College Station, TX (Ocean Drilling Program).

Kollatukudy, P.E., 1976. Chemistry and Biochemistry of Natural Waxes: Amsterdam (Elsevier). 
Lange, C.B., Berger, W.H., Burke, S.K., Casey, R.E., Schimmelmann, A., Soutar, A., and Weinheimer, A.L., 1987. El Niño in Santa Barbara basin: diatom, radiolarian, and foraminiferan responses to the "1983 El Niño" event. Mar. Geol., 78:153-160.

Lange, C.B., Burke, S.K., and Berger, W.H., 1990. Biological production off southern California is linked to climatic change. Clim. Change, 16:319 329.

Mann, K.H., 1982. Seaweed-based systems. In Ecology of Coastal Waters: Berkeley (Univ. Calif. Press), 53-82.

Martinson, D.G., Pisias, N.G., Hays, J.D., Imbrie, J., Moore, T.C., Jr., and Shackleton, N.J., 1987. Age dating and the orbital theory of the ice ages: development of a high-resolution 0 to 300,000-year chronostratigraphy. Quat. Res., 27:1-29.

Müller, P.J., 1977. C/N ratios in Pacific deep sea sediments: effect of inorganic ammonium and organic nitrogen compounds sorbed by clays. Geochim. Cosmochim. Acta, 41:765-776.

North, W.J., 1971. Introduction and background. In Worth, W.J. (Ed.), The Biology of Giant Kelp Beds (Macrocystis) in California: Nova Hedwegia, 32:1-97.

Peters, K.E., 1986. Guidelines for evaluating petroleum source rock using programmed pyrolysis. AAPG Bull., 70:318-329.

Pisias, N.G., 1978. Paleoceanography of the Santa Barbara Basin during the last 8000 years. Quat. Res., 10:366-384.

Prahl, F.G., and Muehlhausen, L.A., 1989. Lipid biomarkers as geochemical tools for paleoceanographic study. In Berger. W.H., Smetacek. V.S., and Wefer, G. (Eds.), Productivity of the Ocean: Present and Past. Dahlem Workshop, Life Sci. Res. Rep., 44:271-289.

Reimers, C.E., Lange, C.B., Tabak, M., and Bernhard, J.M., 1990. Seasonal spillover and varve formation in the Santa Barbara Basin, California. Limnol. Oceanogr., 35:1577-1585.

Reimers, C.E., and Suess, E., 1983. Late Quaternary fluctuations in the cycling of organic matter off central Peru: a proto-kerogen record. In Suess, E., and Thiede, J. (Eds.), Coastal Upwelling: Its Sediment Record (Pt. A): New York (Plenum), 497-526.

Scheffer, F., and Schachtschabel, P., 1984. Lehrbuch der Bodenkunde: Stuttgart (Enke).

Schimmelmann, A., and Kastner, M., 1993. Evolutionary changes over the last 1000 years of reduced sulfur phases and organic carbon in varved sediments of the Santa Barbara Basin, California. Geochim. Cosmochim. Acta, 57:67-78

Schimmelmann, A., Lange, C.B., and Berger, W.H., 1990. Climatically controlled marker layers in Santa Barbara basin sediments, and fine-scale core-to-core correlation. Limnol. Oceanogr., 35:165-173.
Schimmelmann, A., Lange, C.B., Berger, W.H., Simon, A., Burke, S.K., and Dunbar, R.B., 1992. Extreme climatic conditions recorded in Santa Barbara Basin laminated sediments: the 1835-1840 Macoma event. Mar. Geol., 106:279-299.

Schimmelmann, A., and Tegner, M.J., 1991. Historical oceanographic events reflected in ${ }^{13} \mathrm{C} /{ }^{12} \mathrm{C}$ ratio of total organic carbon in Santa Barbara basin sediment. Global Biogeochem. Cycles, 5:173-188.

Sholkovitz, E.R., and Gieskes, J.M., 1971. A physical-chemical study of the flushing of the Santa Barbara Basin. Limnol. Oceanogr., 16:479-489.

Soutar, A., and Crill, P.A., 1977. Sedimentation and climatic patterns in the Santa Barbara Basin during the 19th and 20th centuries. Geol. Soc. Am. Bull., 88:1161-1172.

Stein, R., 1991. Accumulation of Organic Carbon in Marine Sediments: Results from the Deep Sea Drilling Project/Ocean Drilling Program $(D S D P / O D P)$. Lect. Notes Earth Sci., 34: Heidelberg (Springer).

Stein, R., Nam, S.-I., Grobe, H., and Hubberten, H., in press. Late Quaternary glacial history and short-term IRD fluctuations along the East Greenland Continental Margin. In Andrews, J., et al. (Eds.), Late Pleistocene North Atlantic Paleoceanography, Geol. Soc. Spec. Publ. London.

ten Haven, H.L., de Leeuw, J.W., Rullkötter, J., and Sinninghe Damsté, J.S., 1987. Restricted utility of the pristane/phytane ratio as a paleoenvironmental indicator. Nature, 330:641-643.

Thornton, S.E., 1984. Basin model for hemipelagic sedimentation in a tectonically active continental margin: Santa Barbara Basin, California continental borderland. In Stow, D.A.V., and Piper, D.J.W. (Eds.), Finegrained Sediments: Deep-water Processes and Facies. Geol. Soc. Spec. Publ. London, 15:377-394.

Tissot, B.P., and Welte, D.H., 1984. Petroleum Formation and Occurrence (2nd ed.): Heidelberg (Springer).

van Andel, T.H., Heath, G.R., and Moore, T.C., Jr., 1975. Cenozoic history and paleoceanography of the central equatorial Pacific Ocean: a regional synthesis of Deep Sea Drilling Project data. Mem.-Geol. Soc. Am., 143.

Date of initial receipt: 30 June 1994

Date of acceptance: 13 February 1995

Ms 146SR-298 


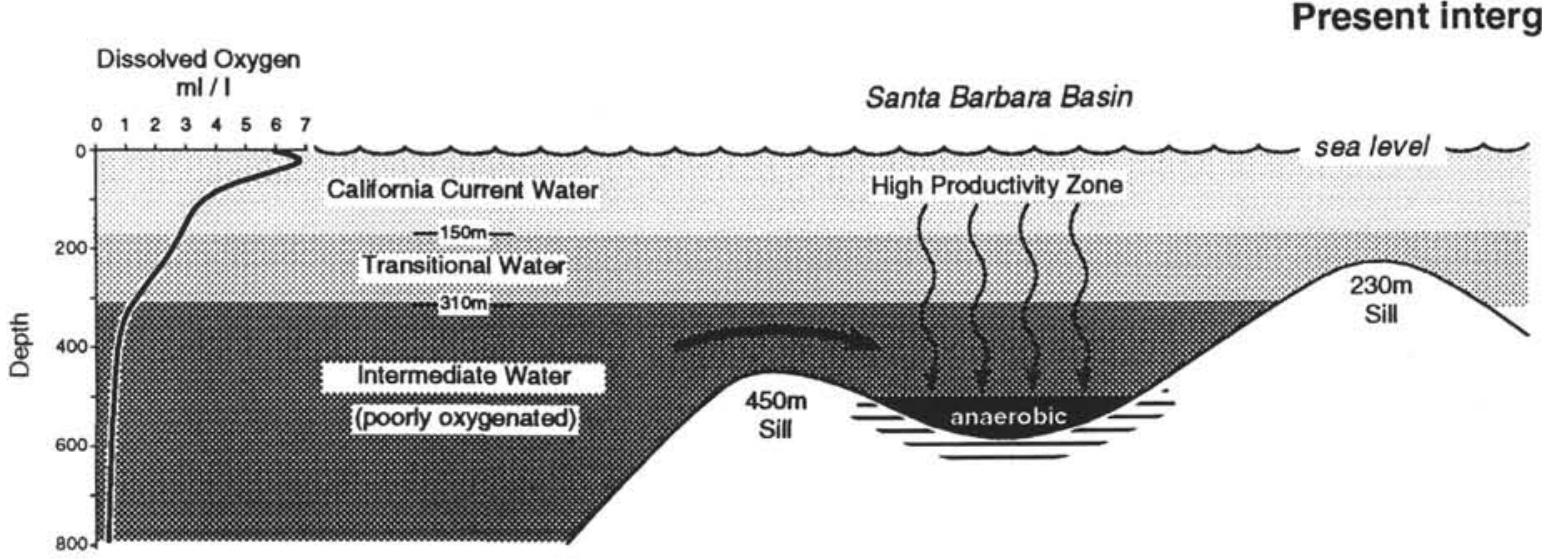

\section{Last glacial maximum model}

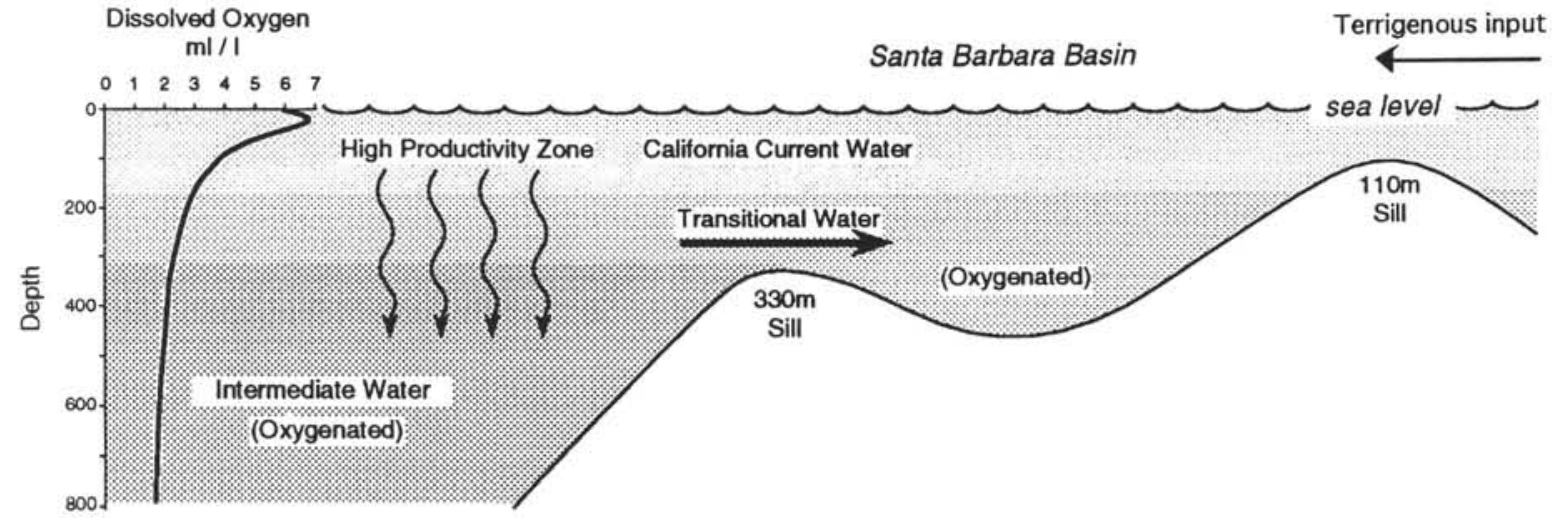

Figure 9. Depositional model to explain organic carbon accumulation in the Santa Barbara Basin and its change between interglacial and glacial times (from Kennett, Baldauf, et al., 1994). 


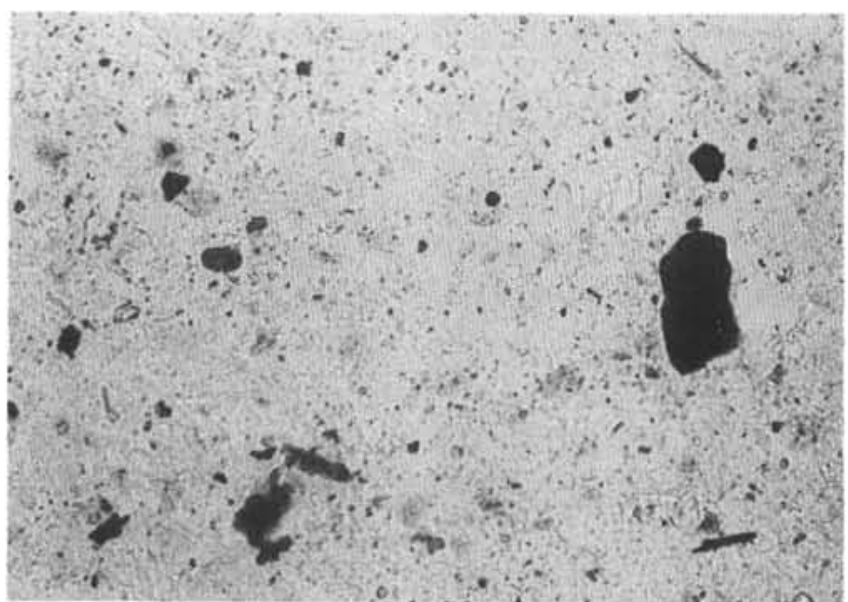

1

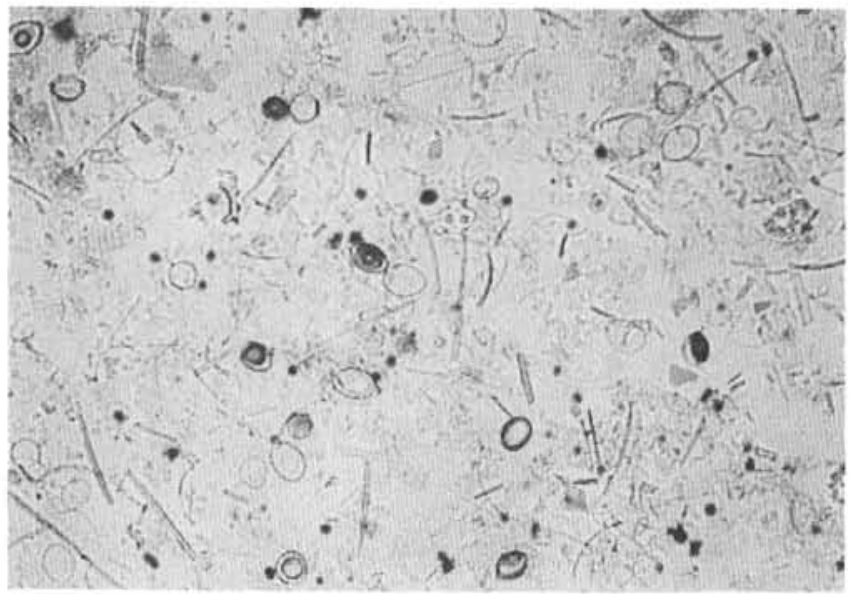

3

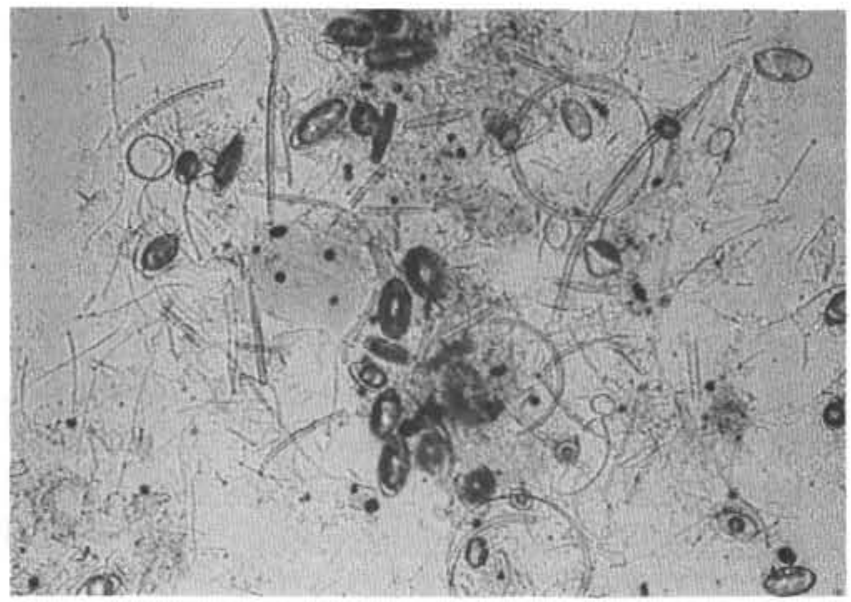

5

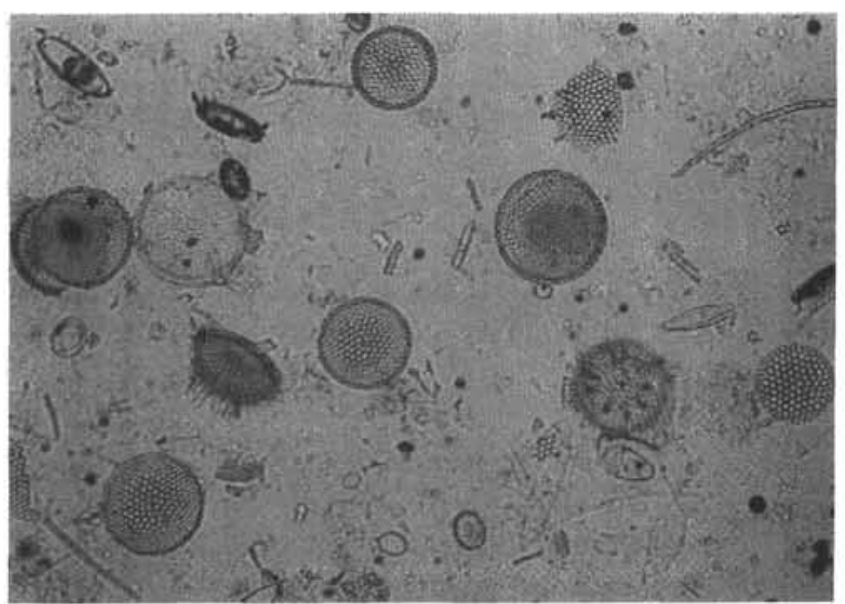

2

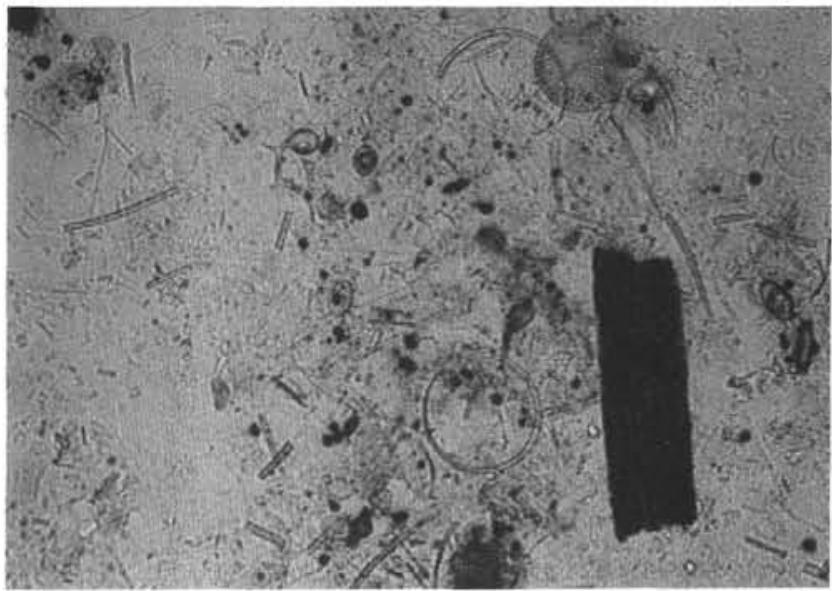

4

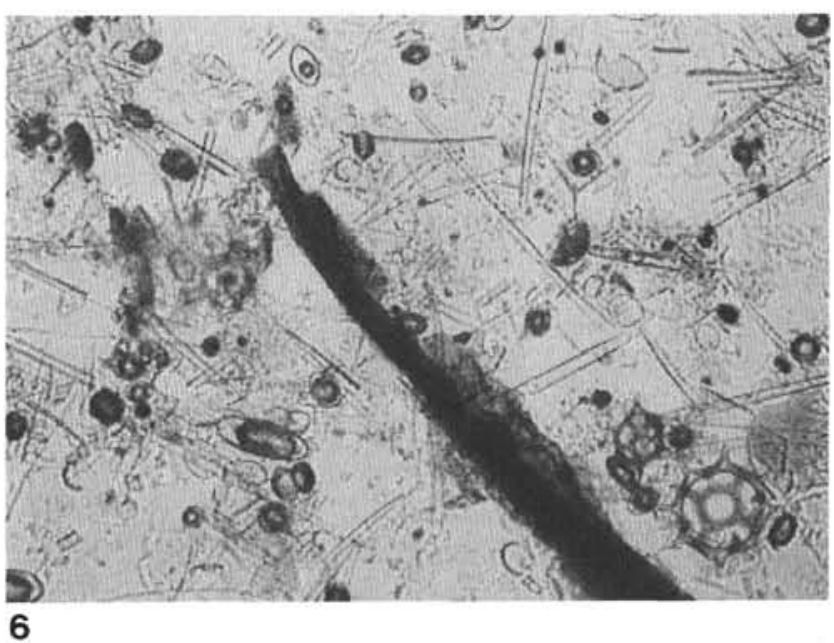

Plate 1. Photographs of smear slides from different lithologies. 1. Sample 146-893A-2H-2, $126 \mathrm{~cm}$. 2. Sample 146-893A-9H-5, 39 cm. 3. Sample 146-893A$11 \mathrm{H}-6,115 \mathrm{~cm}$. 4. Sample 146-893A-13H-7, $135 \mathrm{~cm}$. 5. Sample 146-893A-13H-7, $142 \mathrm{~cm}$. 6. Sample 146-893A-15H-2, $108 \mathrm{~cm}$. 